\title{
ARTESIAN WELLS
}

$$
\text { OF THE }
$$

\section{BELLE PLAINE AREA.}

H. R. MOSNAT. 


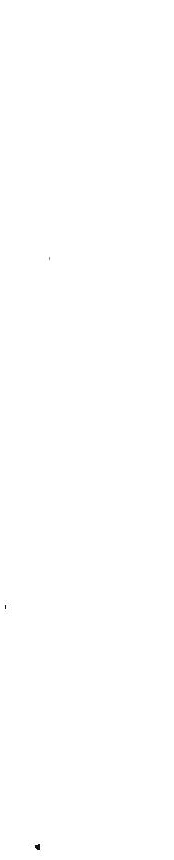




\section{REPORT OF THE ARTESIAN WELLS OF THE BELLE PLAINE AREA.}

BY H. R. MOSNAT.

\section{INTRODUCTION.}

About forty miles east of the geographical center of the state of Iowa, is an area of about 100 square miles occupying a portion of the valley of the Iowa river, and nearly all of the valley of Salt creek, a tributary of the river from the north. This area is apparently like the adjacent country. Its surface is the same-flood plains, valleys and rolling bills, as that of the surrounding territory. However, by drilling to a depth of 110 to 360 feet within this area, artesian wells to the number of about 135 have been struck. Non-flowing artesian wells were secured in the high, rolling land to the northeast of Belle Plaine, Benton county, Iowa, as early as 1882. Four years later a strong flow was struck in the city of Belle Plaine, and later in the same year, 1886, the famous "Jumbo" was allowed to break loose. Thus, for historical reasons, this has been called the Belle Plaine artesian area. The exploration of the basin has not altered the appropriateness of the name, as Belle Plaine is approximately in the center of the basin. 
The general trend of the Belle Plaine artesian area is from northwest to southeast. The southwestern margin probably runs a short distance north of Gladstone, thence southeast through Chelsea. Continuing in the same general direction, the line runs to a point three and one-half miles south of Belle Plaine, where its course appears to change to almost due south, passing through Victor.

The northeastern margin runs in a southeasterly direction a short ristance east of Elberon, passing about a mile east of Irving, and goes almost to Luzerne. Before reaching Luzerne it changes its course to clue south, running to a point about three and one-half miles south of Luzerne, where the direction changes to due southeast, passing through Marengo.

In general, the width of the area is about six miles. About three and one-half miles southeast of Belle Plaine the width diminishes to balf of that, and from this point it rapidly increases to twelve miles, which width it maintains as far south as the area has been explored. The field, as far as explored, extends fiom northwest to southedst, from Vining to Ladora, a distance of twenty miles, diagonally crossing the present valley of the Lowa river.

The wells are most numerous in the flood-plain of the Iowa river, and particularly in the Salt creek valley and westward of it. In all, there are 124 flowing and 11 non-flowing wells. In addition to these there are a few old wells, now filled up. The water supplying all of these wells comes from the same water-bearing vein or aquifer, making very apparent the reasonableness of Professor Norton' definition" of the word "artesian." The very case there supposed actually occurred to the previously flowing wells in the Belle Plaine area, when "Jumbo" broke loose; that is, the other wells ceased flowing. and became "deep wells," "deep borings," etc. After "Jumbo " was controlled the wells which had stopped flowing began to flow again. In the present report the word "artesian" is used in the sense defined by Professor Norton: "a vertical

*"Artesian Wells of Iowa," Iowa Geological Survey, vol, VI, p. 121-8. 
well in which water rises near to or above the surface by natural hydrostatic pressure, consequent upon certain structural conditions."

The Belle Plaine artesian area is one of the most important in glacial drift in Iowa. It contains about one-tenth of the whole number of artesian wells so far drilled in glacial drift in the state. In the accompanying lists on the map, and in the diagrams, Arabic numerals are used to designate artesian wells belonging to the Belle Plaine area; capital letters are used for artesian wells in rock and adjacent to the Belle Plaine area; Roman numerals are used for various non-flowing and weak-flowing artesian wells in rock and adjacent to the Belle Plaine area; small letters are used for various shallow artesian wells in drift, in or near the Belle Plaine area.

\section{EISTOLY OF THE BELLE PLAINE ARTESIAN AREA.}

As remarked above, the Belle Plaine artesian area was cliscovered ahout $188 \%$, in the elevated, rolling country two to four miles northeast of Belle Plaine. Numbers 1, 2, 3 and 46 on the map were the first wells drilled. The water in these wells rose to within twenty-five or fifty feet of the surface. Thes: wells made first class deep wells, and nothing more was thought of it. They were wholly in blue clay, and so were easily drilled and not expensive. It was noticed that the water had a peculiar mineral taste, that it left a red sediment and stain and, after a time, it was observed that the water rapidly corroded iron pipe. No one took the trouble to have the water analyzed. The supply of water was inexhaustible and constant. Live stock liked the water after becoming accustomed to the taste. It, therefore, made a good water for stock, and was used for that purpose only, being pumped usually by windmills.

Hilton Bros., of Boston, needed an unlimited supply of water for their creamery at Belle Plaine. In April, 1886, a 2 -inch well was drilled which proved a pleasant surprise. At a depth of 215 feet, after passing through blue clay, watel' 
was struck which rose from the well curb with a pressure of more than thirty-five pounds per square inch, or to a height of about seventy-seven feet from the surface. This well (No. 6) is located at the eastern edge of Belle Plaine. Immediately other wells were drilled. The flow secured varied with the elevation of the surface, the water in all the wells rising to the same head, about 915 feet A. T. This figure is fairly accurate. A well was arilled on top of a hill in the northern part of Belle Plaine, at an elevation of 918 feet A. T. This well (No. 4), of course, did not flow, but it was a much more reliable indicator of the head than the strong flowing wells. The head of water rose to within three feet of the surface, showing the head to be, at that time, 915 feet.

Shortly after the last mentioned well was completed, the most famous of all Iowa artesian wells was drilled. This well, for its brief day, attracted a popular notice alrnost as wide as the Charleston earthquake, which occurred about three days later, and with which the outburst of water from this well was connected by a romancing newspaper reporter.* Professor Chamberlin remarks that the only similitude of seismic disturbance, as the cause of this well, was in the moral faculties of said reporter. Renewed geyser activity in Yellowstone park, a seismic movement on the opposite hemisphere, the Charleston earthquake and this runaway well at Belle Plaine, were at once connected as factors in a common disturbance of the earth's crust. A relation between the first three may have been possibie, but connecting the well with them was as ridiculous as many of the theories advanced as to the source of the water supply.

"'The notoriety of 'Jumbo,' of Belle Plaine, was strictly that of a member of the criminal class, and began with his resistance to control, and lasted only until his final imprisonment." The accounts of the well given in newspapers were

\footnotetext{
*Note by Professor Calpin la the "Report on the Charleston Earthquake," U. S. Geol. Surveg, Nintl Ann. Rep., p. 443; and Professor Ohamberlin's "The Artestan Well at Belle Plalne Iowa," Science, vol. VIII, p. 276, Sept. 24, 1886.

tNorton, "Artesian Wells in Iowa," Iow a Geol, Survey, vol. VI, p. 350.
} 
in many instances most sensational, their extravagance "increasing according to the square of the distance "from Belle Plaine. European papers published accounts of the water spouting hundreds of feet into the air, with a roar that could be heard for miles, and even pictured people being rescued by boats from the third and fourth stories of houses!

During the summer of 1886 six flowing wells bad been drilled in drift at Belle Plaine; numbers 4, 5, 6, 7 and 10 on the map. The record of the strata of the seventh well, number 9, "Jumbo," as given by Professor Chamberlin, and quoted by Call and. Norton, is as follows:

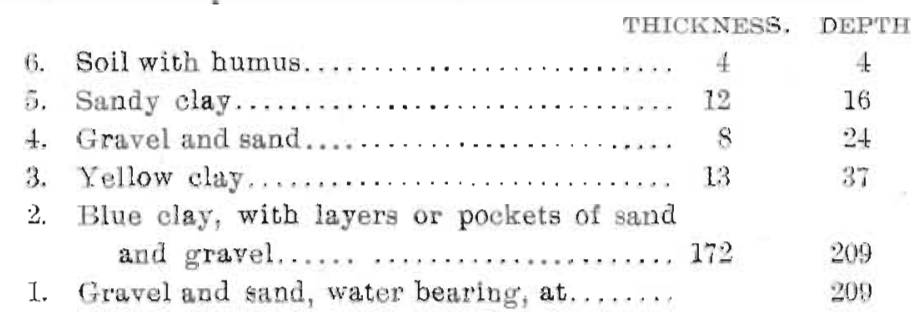

As Professor Chamberlin remarks, the record lacks detail, and possibly precision. But inaccurate as the record no doubt is, it is the most careful that has been kept, and satisfactorily shows the geological structure which will be considered under that heading. 'This well is a typical well on low ground. The elevation of the curb is 811 feet A. T. A local history of the well is entitled: "A Complete History of the Jumbo Artesian Well of Belle Plaine, Iowa, Known as the Eighth Wonder of the World," second edition, by A. C. Huston.

Professor Norton's account of the history of "Jumbo" is accurate, and is repeated below with some additional facts.

"'The seventh well, 'Jumbo,' was drilled on lower ground than any of the others, and reached the water-bearing stratum of sand and gravel at 193 feet." (A. T. 811.)

"The beginning of the trouble lay in the fact that the driller attempted to use the force of the flow in reaming out the twoinch bore, which he had put down for want of a larger drill, 
to three inches, the dimension specified in the contract. This task the water speedily accomplished in the unindurated clays and sands, but not stopping there went on and soon enlarged the bore to over three feet in diameter." When the driller saw the result of his inexcusable carelessness, which result he ought to have foreseen, he hastily decamped and was not heard of until the popular excitement had subsided.

The force of the water was sufficient to throw out twobushel sacks filled with sand. "Through this three-foot shaft the water boiled up in a fountain five feet in height" see illustration - "the press reports giving several hundred feet as the height of this fountain, were exaggerated - flooding streets and lawns, and covering them with sand. It was estimated that from 500 to 1,000 carloads of sand were discharged from the well. The quantity was certainly so great that only with the greatest effort could the ditches be kept open to carry off the water. Gravel and small pebbles of northern drift, representing a great variety of northern rocks, were thrown out."

The writer has a flint bowlder weighing two and one-fourth pounds which was thrown out by "Jumbo." There may have been others even larger. It is not necessary to suppose that these larger stones came from the bottom of the well, as bowlders are occasionally encountered in drilling through the till sheets. Pieces of fossil wood, some of them two or three feet long and four or five inches thick, were thrown out. These, no doubt, came from the forest bed which represents the Aftonian interglacial stage between the Kansan and subAftonian till sheets. Small boys, of which the writer was one, put fossil wood, pebbles and sand into bottles and sold them to visitors to the well during the few days of its fame.

"The maximum flow of water was variously estimated at $5,000,000$ to $9,000,000$ gallons per day, 30,000 to 50,000 gallons per minute. Two weeks after the well was drilled Professor Chamberlin, of The University of Chicago, calculated its discharge at 3,000,000 gallons per day; 2,000 gallons per minute. 
The enormous flow rapidly drew down the head until the other wells ceased Howing.

"The attempt to case and control the well continued from August 26, 1886, the date when the water was struck, to October 6,1887 , when the task was successfully accomplished. During this time the well, 193 feet deep, devoured, as the local historian recounts, 163 feet of 18-inch pipe, 77 feet of 16 -inch pipe, 60 feet of 5 -inch pipe, an iron cone 3 feet in diameter and $2+$ feet long, 40 carloads of stone, 130 barrels of cement, and an inestimable amount of sand and clay." Nontrm.

After "Jumbo" broke away, the head of water in the the other wells fell rapidly until those on Main street-elevation 848 and 846 feet A. T. - ceased to flow on August 30th; 4 days after "Jumbo" began his escapade. The head diminished 67 feet in four days, an average of almost 17 feet per day. By September 7 th the water had uropped to 838.5 feet A. T., a fall of 1.3 feet per day. From that time until September 20 th the head diminished at an average of 3 inches per day, or to 835 feet A. T. The head remained at this point for about 3 days - 24 feet above "Jumbo"-and then began to rise until, on November $22 \mathrm{~d}$, it was within 5 inches of the surface at Main street, or an average rise of .6 foot per day. The well was then closed for the winter. The head continued to rise until about the present level was reached. About 1890 well No. 88 was allowed to break away by careless drilling, ancl a second "Jumbo" occurred. This one did not act just like the first one. Instead of coming out in one stream, the water flowed from every gopher hole over several acres. It probably spread out in an underlying bed of sand. This well again drew down the head. Little was done to shut it off. It was allowed to run until it had choked itself up, and all the other wells had again ceased flowing. Witbin two or three years the head had risen to about what it is at present, 864 feet A. T., 51 feet below its original level. At present the flow is gradually growing weaker. 
Up to 1890 about 50 flowing wells had been drilled. Now there are about $12 \pm$ such wells. The owners of many of the wells are very careless and let them run much more than is necessary.

\section{GEOLOGICAL STRUCTURE.}

The record of strata passed through in drilling "Jumbo" has been given above. The well is a typical well on low ground: The record with the geological interpretation is as follows:

\begin{tabular}{|c|c|c|}
\hline (i. Soil with bumus $\ldots \ldots \ldots .+$ & $\begin{array}{l}\text { DEPTH. } \\
+\end{array}$ & $\begin{array}{l}\text { INTERPRETATION. } \\
\text { RECent. }\end{array}$ \\
\hline 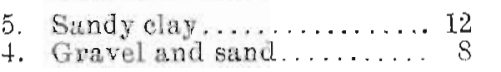 & $\begin{array}{l}16 \\
24\end{array}$ & $\zeta$ Loess. \\
\hline 3. Yellow clay............. 1: & 37 & $\left\{\begin{array}{l}\text { Weathered } \\
\text { Kansan till, } \\
\text { or loess. }\end{array}\right.$ \\
\hline $\begin{array}{l}\text { 2. Blue clay, with layers or } \\
\text { pockets of sand and } \\
\text { gravel and occasional }\end{array}$ & & TKonogn \\
\hline 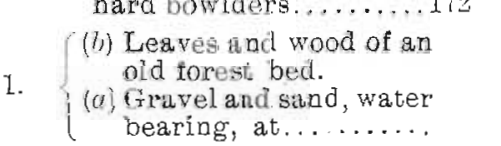 & 209 & $\begin{array}{l}\text { Aftonian } \\
\text { interglacial } \\
\text { stage. }\end{array}$ \\
\hline
\end{tabular}

Stratum number 6 is composed of vegetable mould, soil, etc. It is of about maximum thickness in this well, as the well. is one of those within the flood plain of the river. In the wells on higher ground this stratum is about two feet thick.

About three miles directly north of Belle. Plaine runs the line which marks the southern limit of the Iowan drift. This line has been traced as far west as the western line of Johnson county, and has been located again at Toledo, but it has not been traced across Benton county and the eastern half of Tama. From the topography of the county it seems probable that the explored portion of the Belle Plaine area lies almost, if not quite, entirely outside of the margin marked by the Iowan ice, in which respect this field differs from other artesian areas in Iowa in which the wells penetrate only the glacial 
drift. But it is certain that the intake area is somewhere inside the margin of the Iowan drift sheet.

The margin of the Iowan ice sheet not being yet definitely known in the area under consideration, it is not possible to say whether any of the wells of the Belle Plaine area, are within the moxaine of the Iowan glacier. The Belle Plaine artesian area, as far as known, is of Kansan topography, except where modified by the valleys of the Iowa river and Salt, ereek.

The line of the Iowan ice probably coincides with a portion of the northeastern margin of the Belle Plaine area, shown on the map. The margin of the ice probably ran about two miles north of Luzerne, and thence followed the line of the margin of the Belle Plaine area running west. About a mile east of Irving the Iowan margin turns to the northwest and north and runs to a few miles north of Elberon, where it probably turns westward, passing several miles to the north of Vining, thence in a western and southerly direction, crossing the Belle Plaine area and running through Toledo, where it has been traced for a short distance. This hypothesis makes every well in the Belle Plaine area without the margin of the Iowan glacier. There is no reason to doubt that where the elevation is not too great, flowing wells in this aquifer will be found within the Iowan area. Many artesian wells are within the Wisconsin moraine in northern Iowa. Such wells are less common in the Iowan drift. Fifty to seventy-ive miles to the northwest are numerous shallow Howing wells in glacial drift. These, hovever, are within the moraine of the Wisconsin ice sheet. It is not probable that the aquifer is the same as that in the Belle Plaine area.

Strata Nos. 5 and 4 belong to the loess. Stratum No. 3 may be loess, but it seems more likely that it is partly weathered Kansan, which was not differentiated from the loess. The loess deposits in the neighborhood of Belle Plaine are rather heavy, so a total thickness of twenty to thirty feet of loess, in its thick places, is not excessive. Stratum No. 2 varies 
with the altitude from about eighty-three feet in thickness in No. 40, to 322 feet in No. 29. This glacial till is the Kansan. It has the characteristic pockets or layers of sand and gravel, and occasional bowlders. At forty to fifty feet from the base of the till, leaves and sticks are often encountered, which are from the Aftonian interglacial stage, just below the Kansan, and have been mixed with the clay during the grinding up process to which the till was subjected. The same phenomenon is well shown in the cut at Oelwein", where wood from the Aftonian forest bed is found twenty feet above the base of the Kansan till.

Sometimes bowlders are encountered by the drill. With the light apparatus used it is almost impossible to go through these hard bowlders, and they are apt to be struck slantingly, which bends the pipe out of line and interferes with further drilling. Accordingly, when a bowlder is struck, it is usual to pull up the casing and drill another well near by. A move of four or five feet usually avoids the bowlder in the second drilling. It is cheaper to dig a new well than to drill through one of these hard bowlders.

Stratum No. 1 is the aquifer. It is of the Aftonian interglacial stage. In the Belle Plaine artesian area it is com-

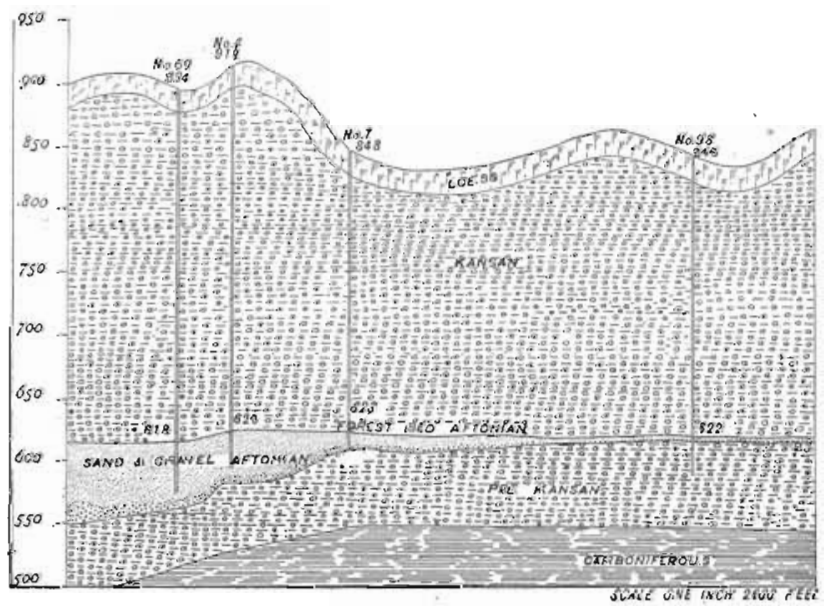
posed of-

(b) An old forest bed - mention of which is omitted f rom Chamberlin's record. The maximum thickness is a bout two feet. The w o o d appears to be from conilers.

Fia. 53. Section showing variation in Aftonian gravels at Belle Plaine. Northwest to southeast.

*Proc. Iowa A cad, Sclences, vo'. IV, pp, 54-69. 
(a) Sand and gravel, forming the aquifer. This stratum varies from two feet in thickness, as in No. 93, to more than forty-six feet, as shown in Nos. 60 and 4. Again, at Ladora, the aquifer is thirty to forty feet in thickness. (See figures Nos. 53 and 54 .)

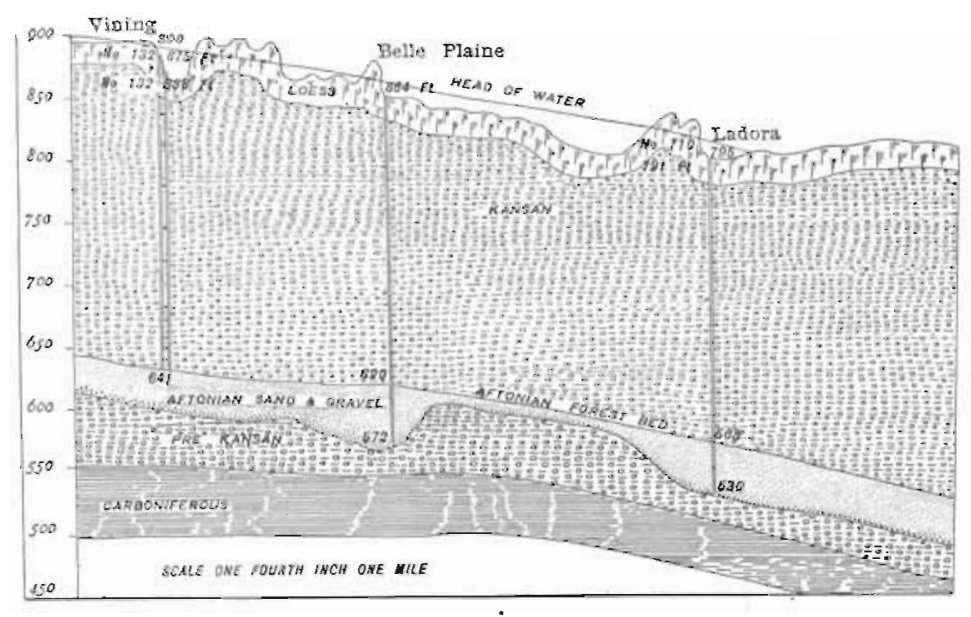

FIo. 5i. Sectlon nortbwest to scutheast-VIning to Ladora.

At some places, as at Afton Junction, the gravel and sand is found above the forest bed. At Belle Plaine the gravel and sand is below the forest bed. At Afton Junction the gravel and sand may have been deposited by water flowing from the front of the advancing Kansan ice; at Belle Plaine the gravel and sand were probably laid down by streams attending the retreat of the pre-Kansan ice invasion. It may be asked how the great Kansan glacier passed over this unindurated deposit of gravel and sand instead of carrying it away. The answer is that the sand and gravel was full of water, which, upon the near approach of the glacier, was frozen. Thus the ice passed over the frozen sand and gravel without disturbing it any more than it would disturb hard rock.

The wells vary in depth according to surface elevation. The altitude of the aquifer is fairly constant. At Vining it is 641 feet A. T. At Belle Plaine, eight miles to the southeast, its elevation averages 620 feet $A$. T. At Ladora, eleven miles 
farther towards the southeast, its elevation is 565 feet A. T., a fall of 76 feet in 19 miles, or an average of 3.5 feet per mile. The elevation of the aquifer diminishes relatively faster toward the southeast. From Vining to Belle Plaine the average fall is 2.6 feet per mile; from Belle Plaine to Larlora, 5 feet per mile. The well diggers raim that they can tell within a few feet the depth at which the aquifer will be struck, provicled they know the height of the point at which the well is to be bored. The upper surface of the aquifer is more regular than the base, showing that the gravel and sand were laid down on an uneven surface. The tendency, of course, was for the gravel to be deposited over the lowest places, leveling them up. For example, in number 7 the altitude of the base of the aquifer is 615 feet A. T., elevation of the surface is 620 feet A. T. In number 4 , about 60 rods north, the base is less than 590 feet $\mathrm{A}$. T., the surface is 615 feet $\mathrm{A}$. T. In number 60 , about 15 rods farther north, the base is less than 582 feet $A$. T., the surface is 618 feet $\mathrm{A}$. T. In well number 98, which is about balf a mile southeast of number 7 , the elevation of the base of the aquifer is 620 feet $A$. T., the surface is 622 feet 1 . T. Thus within about three-quarters of a mile the base of the aquifer varies more than 38 feet, while the surface varies only 7 feet.

The aquifer consists of fine sand at the top, changing to gravel at the bottom in the thicker places. In number 6, where it is 5 feet 3 inches thick, there is a little gravel at the bottom. In number 98 , where the aquifer is only 2 feet thick, there is no gravel; the whole thickness is sand. In number 4, 25 feet of sand were penetrated before encountering gravel. In number 60, 46 feet of sand were passed through before reaching the gravel. The thickness of the gravel at these points is unknown. At Ladora the drill penetrated 30 to 40 feet of sand before reaching the gravel. The whole thickness of the aquifer has not been penetrated in any of the thick places, so it is impossible to give its maximum thickness. It 
was found to be composed of 46 feet of sand in number 60 , with gravel of unknown thickness below.

In drilling the wells the casing is kept full of water during the boring to prevent the sand from rushing up and filling up the pipe when the aquifer is penetrated, and preventing the water from flowing. Where this is not done it may take days to pump out the sand with a sand pump. In fact, it may be cheaper to dig a new well, and avoid the mistake. Several wells have become stopped up by sand. Ho prevent this a strainer is usually put at the bottom of the casing. Wherever possible it is seated in gravel. Where the vein is very thin, as in number 98, only fine sand is found, and the well drillers have trouble in seating the strainer.

The aquifer thins out toward the margins of the artesian area, causing wells near the margin to have a relatively weak pressure. It seems probable that to the northwest of Belle Plaine the aquifer is thicker, and contains more gravel than south and east of Belle Plaine. As in the first mentioned portion of the field, with the exception of wells near the margin of the area (as numbers 8.3 and 2), all the wells are normal in their flow. In the latter mentioned portion of the field there are two groups of wells where the head is abnormally weak. In numbers $83,40,41,89$ and 58 the weak flow is caused by the fact that the wells are near the margin of the area; but number's 143, 142, 118, 152 are apparently well towards the center of the field. The explanation of their weak flow is consictered later.

The dip of the aquifer to the southeast is about 3.5 feet per mile, which seems slight. From Chelsea to Marengo, eighteen miles in an air line, the Iowa river falls 150 feet, or eight feet per mile. But the aquifer was laid down under very different conditions from that of the flow of a river in a regular channel. It is also possible that there have been changes in level since it was laid down, which have reduced its dip. The limits of the aquifer are, of course, the same as the boundaries of the Belle Plaine artesian area, which are 
traced above. The opinion has been advanced that this extensive subterranean hydrographic basin is an immense pre. glacial river valley, now entirely filled up ancl obliterated. It must be remembered that the present drainage of this portion of the state has littic or nothing in common with its preglacial drainage. *

Of the Belle Plaine artesian field, Call says that "there are indications which point toward the existence in this ar"ea, either, first, of a great preglacial valley which has become filled with morainic materials, or second, to the existence of a great fault." + Reference to figure 55 will show that no

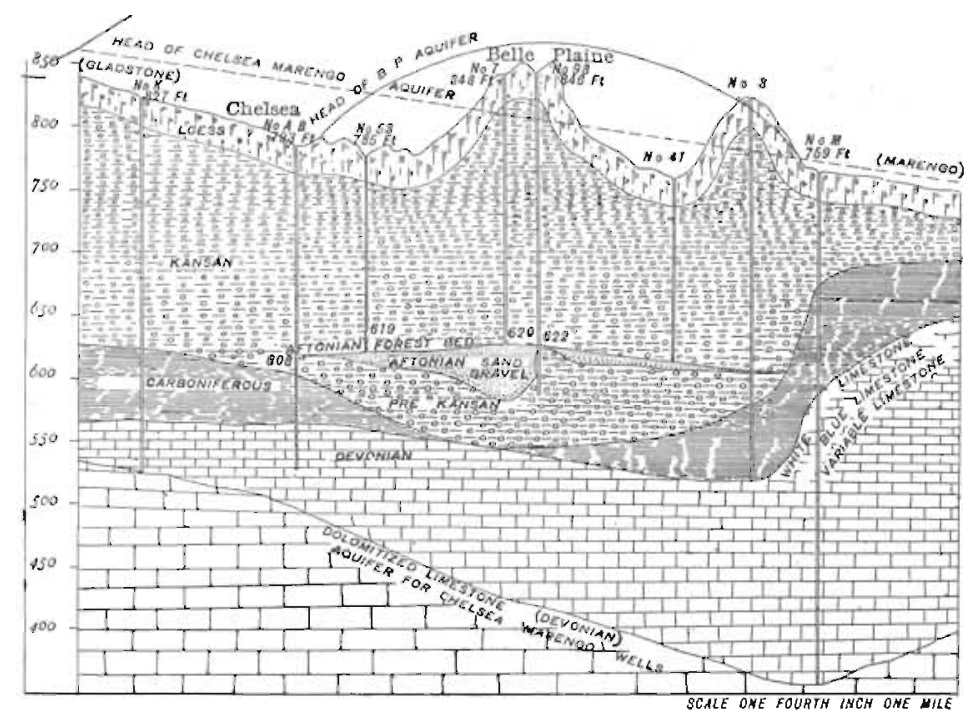

Fia. 55. Diagonal cross-section-Gladstone to Marengo.

such geological structure as a great fault need be supposed to explain the Belle Plaine area. Call suggests, further, + "that the water may be derived from the Cedar river," which he considers may be tapped below Waterloo, the water finding its way southward through a very wide and deep channel, from which it rises at Belle Plaine. This point will be brought up again in considering the source of the water.

*Call: "Yowa Arteslan Wells," Weather and Orop Servlce, vol. III, March, 1393, p. 4.

+Ib., p. 4.

rib, p. 7 . 
Professor Norton" "regards the Belle Plaine area as a normal artesian basin in glacial drift, and does not sympathize with any view of the derivation of its waters through a great fault or by the subterranean diversion of a river." With a better knowledge of the area it seems conclusive that the artesian basin occupies a preglacial river valley, now completely filled up and obliterated.

There is positive evidence of a glacial till below the aquifer. In one boring, well No. 98, eighteen feet of blue clay were penetrated below the aquifer. It is not known how much thicker this lower till may be. In well No. III the elevation will not explain the 240 feet of drift there found. To the west, in Nos. 41, 40, 89, the glacial till is but eighty to 120 feet in thickness; to the east are wells, Nos. M and L, with only eighty feet of blue clay; to the north is No. II, with about the same thickness of drift. It is possible that No's. I, II, III, and No. C, penetrate the same aquifer; the white Devonian limestone just below the Carboniferous shale. The altitude of No. II is too great for a flow, and it seems that the well should be deeper, but it may lie more distant from the margin of the Belle Plaine basin than Nos. I and II, and the

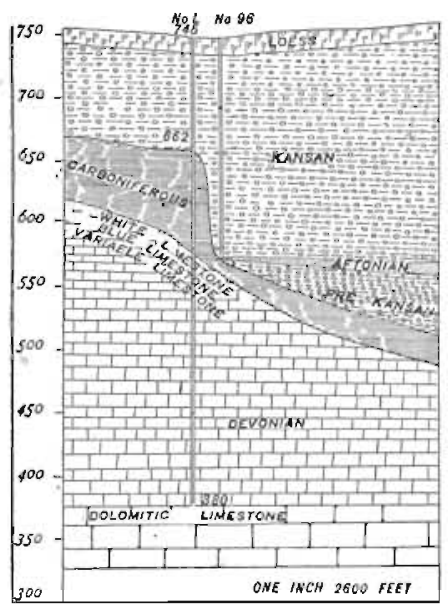

Fia. 66. Section slown by Mareugo wells. conditions in it may be similar to those at Marengo. (See figure 56.) No. III is included in the Belle Plaine field, because of the great thickness of the drift there shown. The record of well No. III is very brief: " 305 feet deep, last fifty feet in shale." The elevation is such that the Belle Plaine vein would not flow, and it is very likely that the Belle Plaine aquifer was penetrated without its being noticed. The well was drilled in 1886, or about the time the Belle Plaine flow was struck at

*Op. cit . p. 352 .

$43 \mathrm{G} \operatorname{Rep}$ 
Relle Plaine. It was not then known that the latter area was so extensive and the well digger was not expecting to encounter the Belle Plaine aquifer at Marengo. The head of the Belle Plaine aquifer would, even at that time, have been a few feet below the surface, and it is probable that the well digger did not notice the vein, if it was struck.

Number III shows 240 feet of drift, which seems excessive for this point. About four miles northward, within the Belle Plaine field, are several wells at a greater elevation of curb, which show only 20 to 230 feet of drift above the aquifer, which is perfectly normal, considering the elevation. This well shows an excess of thirty-five feet of blue clay. The explanation seems to be given by well number 98 , where the drill was stopped in blue clay, eighteen feet below the Belle Plaine aquifer, in a glacial till of sub-Aftonian or pre-Kansan age. Number III gives some not very satisfactory evidence as to the probable thickness of this lowest glacial till, which here appears to be about thirty-five feet.

The pre-Kansan drift sheet has been discussed by $\mathrm{Mr}$. Bain, * who remarks that the pre-Kansan shows evidences of erosion. The inequalities of the base of the Aftonian gravels at Belle Plaine point to an irregular pre-Kansan surface. If the gravels were laid down during the retreat of the pre-Kansan ice, by streams produced by the melting ice, there could have been but little erosion of the surface on which the gravels were spread. It is not necessary, however, to suppose that the upper surface of the till, as left by the ice, was perfectly level.

Over the territory of the Belle Plaine artesian area the evidence of a depression in the surface upon which the Aftonian rests is that in the borings, even when not much beyond the margin of the Belle Plaine area, much less glacial till is penetrated than in the: wells within the Belle Plaine area. Number I penetrates a few feet of shale and has a total depth of only 185 feet, while neighboring borings penetrating the

*"The Aftonlan and Pre-Kansan Deposits in Soutbwestern Iowa." Proc. Kuwa Academy of Sclences, rol. V, p. 37. $1 \& 98$. 
Belle Plaine aquifer, with a lower altitude of curb, show thirty-four to forty feet more depth, though passing through only a portion of the aquifer. Number 32 , which is about a mile southward and west, has a depth of 220 feet, while the altitude is less by perhaps twenty feet. Numbers $80,81,82$ show the same fact. The same condition of things towards the west and northwest is proved by numbers 83,84 . About six miles towards the southeast is the next boring, a short distance outside the Belle Plaine area. The curb of number II has an elevation of about 850 feet A. T., and, although the boring is only 100 feet deep, a few feet of shale were penetrated, making it probable that the margin of the Belle Plaine area is at some distance. The thickness of the glacial till at this point is about eighty feet. Two or three miles to the west are borings, partly penetrating the Belle Plaine aquifer, where 80 to 120 feet of till is shown; the altitude being 770 to 810 feet A. T., as wells numbers $40,41,89$ show.

About two miles farther south is number III, having an elevation of about 830 feet A. T. Like numbers $I$ and C, the flow is weak. There is no strong flow from this vein, which is in the white Devonian limestone, just below the Carboniferous shale. Proceeding eastward, numbers $\mathrm{M}$ and $\mathrm{L}$ show only forty-five feet of glacial till before encountering shale. At Marengo number $y$ is but a few rods south of number $\mathrm{L}$, but has about 100 feet more of glacial till. Along the entire line traced there is within the Belle Plaine area a greater thickness of glacial till than outside that area. At Marengo the excess is about 100 feet within a few rods; in other places the change is not known to be as sudden or extensive. A corresponding relation of till and shale can be shown along the western margin of the Jielle Plaine area.

The wells in Richland and Otter Creek townships (numbers F, G, H, I, J, K) vary from 250 to 320 feet in depth, with an average altitude of 827 feet A.- T., and about 163 feet of glacial till above 80 or 100 feet of Carboniferous shale and a few feet of Devonian limestone and dolomite. Number 29 
has an elevation of about 975 feet A. T., and 323 feet of Kansan till, making the upper surface of the aquifer about twelve feet below the base of the glacial till one or two miles westward. As has been remarked, the aquifer appears to be thick in this portion of the field. Farther southeast, at Chelsea, two wells, numbers $\mathrm{A}$ and $\mathrm{B}$, have been drilled into the same aquifer as $\mathrm{F}, \mathrm{G}, \mathrm{H}, \mathrm{I}, \mathrm{J}, \mathrm{K}, \mathrm{L}$ and $\mathrm{M}$. In these two borings glacial till to the thickness of 163 feet was penetrated. A very weak vein of water was struck just above the shale. This vein flowed a stream about the size of a straw. The well drillers believe that this is the Belle Plaine vein. This is not probable, however, because its depth is too great. Below the shale, which is here only thirty feet thick, a very strong flow was struck in number A. Number B is a weak flow, because it was never well opened up into the aquifer. In $A$ it seemed that a fissure was penetrated. The drill dropped several inches. The altitude of the curb of $\mathrm{A}$ and $\mathrm{B}$ is 793 feet A. T. Number 53, two miles eastward, has an altitude of 785, and it penetrates 123 feet of Kansan till. The base of the till is 619 feet A. 'T.; in numbers $A$ and $B$ the base of the till is 608 feet A. T., or eleven feet lower than in number 53 , which is a typical well of the locality in this respect. This is probably due to gravel not being deposited at Chelsea, the Kansan till lying directly above the pre-Kansan at that point. Wells V, VI, VIII have an elevation of about 838 feet A. T. They show about thirty feet of shale, above limestone, in which the aquifer occurs. These wells show about sixty feet of till, its base being about 740 feet A. 'T. In numbers IX and XII no shale is reported. The drill passed directly from the till to Devonian limestone. The elevation of these wells is about 830 feet A. T. The base of the till is about 620 feet A. T. The elevation of number 31 , which is a mile or two miles north and west, is 770 feet A. T. The base of the till has an altitude of 615 feet A. T. From number IX the line of the western limit of the Belle Plaine aquifer can be no farther traced until it appears again at Victor, which is as far 
south as the wells have as yet been drilled. The flow here becomes too weak from friction to flow strongly.

It is unnecessary to believe that this great trough is the result of a great fault, or a broad syncline. An obliterated river valley is the most natural and reasonable explanation. The variation in the thickness of the shale and the limestone point towards that conclusion, and all the known facts are perfectly consistent with it and with no other.

This increased thickness of the drift means that the altitude of the floor upon which it was laid down was lower than the surrounding land. That floor is the Aftonian gravels. It has already been shown that these gravels are laid down on an uneven surface of glacial till. It is reasonable to suppose that the streams produced by the melting of the ice during the advance of the Kansan followed, in a measure at least, the pre-existing river courses. The pre-Kansan till sheet, as has been noted, appears to be thin; at any rate it was not thick enough to fill the depression. The condition of the valley at the close of pre-Kansan was probably similar to that of the interglacial valley at Mason City, which belongs to the interval between the Kansan and Iowan ice invasions, ${ }^{*}$ where the Iowan till was not sufficient to fill the valley. The rocky bluffs on either side still rise to a height of forty feet. The valley at Belle Plaine was much wider, averaging about six miles, while the depth is at present unknown.

Probably the valley was first a great preglacial river valley cut in the Devonian. The stream was revived after the Carboniferous, and was afterwards partially filled up by the preKansan glacial till. Then the Aftonian forest grew, and possibly a river again occupied the region. Finally the great invasion of the Kansan ice completely filled up and obliterated the river valley, blocking it with till, through which an entirely new and distinct valley has been cut by the Iowa river. This present river valley obliquely crosses the old valley; their coincidence is wholly accidental.

*Iowa Geol. Survey, vol. VII, p. 125. 
A letter from Professor Beyer informs the writer that a thesis by "Mr. Leverett gives records of certain wells in Story county which appear to indicate depressed areas in the old surface, and suggests that these depressions may be one and the same." Mr. Call t takes this as evidence of a preglacial river valley. If there is a preglacial river valley there it does not seem likely that it is the same as that found in the Belle Plaine area. Shallow flowing wells are very common within the territory covered by the Wisconsin glacier, and similar preglacial drift-filled valleys are not uncommon. Flowing wells in glacial till are much less common in the region occupied superficially by the Iowan drift, and the Belle Plaine area is so far the only one in Iowa known to be outside the margin of the Iowan ice. To this exception must be added the small area in Honey Creek township and mentioned below.

Wells numbers dd, ee, ff, gg and $\mathrm{bh}$-the first two of which flow five feet-form a local artesian area, explained by local conditions. It is remarkable in being wholly out of the Iowan drift-and of course the Wisconsin as well-both as to basin and intake area. The source is probably in the elevation to the south. The area is purely local, and probably does not extend over an area of more than three or four square miles.

The non-flowing wells to the southwest of the Belle Plaine area are of interest in showing that the general dip of the country rock is towards the southwest. This is the normal dip for this portion of the state. The wells outside the Belle Plaine area, at and near Chelsea and Marengo, show that below the pre-Aftonian glacial till is thirty to eighty feet of Carboniferous shale. Just below this shale weak flows were found in numbers I, III, $\mathrm{C}$ and XII, probably in Devonian limestone. Below this shale is six to twelve feet of white Devonian limestone, then twelve to fifteen leet of blue limestone, also Devonian, then a few feet to 250 feet of variable stone, described as gray, pink, brown, etc. This last is also 
Devonian. Norton* states that the Devonian "probably somewhat exceeds 300 feet immediately west of its outcrop in central Iowa." Wells numbers L, M would seem to verify the statement. The Chelsea group appears to contradict it. The water comes from a so-called "white sandstone." It is hard to explain the occurrence of sandstone at this elevation and in this section of the state. It is most likely a granular dolomite which is broken up by the drill, giving it the appearance of sandstone. It is probable that it is the dolomitic phase which changes, and not the thickness of stratum. In several of the Chelsea wells the flow appears to be found in a crevice in rock. Crevices are characteristic of dolomite. A fex of the Chelsea wells, as number B, do not flow strongly. "Shooting" these weak-flowing wells with nitroglycerin, as gas wells are shot, might increase their flow by opening ul crevices in the rock, thus giving less impeded channels for the water. The head from this aquifer conforms to Professor Norton's map, showing isopiestic lines for head above sea level of water in Iowa artesian wells not in drift. $t$ The head at Chelsea is about 860 feet A. T.; a little stronger than might be expected. At Marengo the head is about 750 feet A. T.; not quite as much as it theoretically should be. The flow is reported as sixty gallons per hour, which would indicate a head of only a few inches. A head of one foot, from a three-inch pipe, will flow 4.44 gallons per second. The flow of this well would probably be increased by "shooting."

Belle Plaine is one of the few cities of more than 4,000 population in lowa which have no system of waterworks. By drilling to a depth of about 450 feet a moderate artesian flow would be obtained on low ground. But the water would be but little better than the Belle Plaine vein, as the analysis of the Marengo well shows. At a depth of about 1,300 feet, however, a moderate flow of excellent water will be found in the Saint Peter sandstone.

*Artesian Wells of Iowa, Iowa Geological Survey, vol. VI, p. 148

top. cit., Plate vilt. 
THE FLOW OF WATER FROM THE BELLE PLAIN] AREA.

The phenomonal flow of "Jumbo" has already been mentioned. The average head of the 124 flowing wells is 38 feet, that figure being the result of the sum of heads divided by 124. This is the head from the curb, or surface of the ground. A head of 38 feet equals a pressure of almost 17 pounds per square inch.

The velocity of flow from curb, in feet per second may be represented by $v$. According to the well known formula for the flow of water from an orifice, $v$ equals the square root of $2 g h$, where $g$ equals the acceleration due to gravity; or 32.16 feet, and where $h$ equals the head in feet, in this case 38 . The square root of $9 g$, or 2 times 32.16 is about 8.02 and the square root of 38 is about 6.15 ; 6.15 times 8.02 equals 49.32 , the velccity of the flow in feet per second. This does not take friction into account. The solid contents of 1 foot length of a 3-inch pipe equals .3679; 49.32 times by .3672 equals 18.11 gallons theoretical flow per second; $1,086.6$ gallons per minute; 65,196 gallons per hour, or $1,564,704$ gallons per day .

The wells are nearly always shut off to about 15 gallons per minute. As nearly as can be determined that is the average actual flow per well. This gives a total flow from the whole aquifer of 1,860 gallons per minute; 111,600 gallons per hour; 2,678,400 gallons per day; 977,616,000 gallons per year, and in the twelve years since the wells have been discovered the total amount of flow has been about 11,731,392,000 gallons. The two periods during which the water flowed little, are more than compensated for by the excessive flows causing those diminutions. The total amount of water is equal to about two-thirds the average monthly discharge of the Wisconsin river.*

This water comes from the rainfall somewhere to the northwest of Belle Plaine, probably not more than fifteen to twentyfive miles distant.

*Greenleaf, "Report on Water Power of the Mississippl Rlver," p. 20, vol. XVII, Tenth Census U, B. 
The rainfall in this portion of the state is slightly below the average. The average rainfall for Iowa is 34.88 inches per year. The early records show a higher average but this is probably due to the fact that the earlier observers were stationed at points since proven to have more than the normal rainfall for the state.

It would seem that thirty inches per year is a conselvative estimate for the locality under consideration. Of this amount it may safely be assumed that one-fourth finds its way to the aquifer. Professor Norton* quotes DeRance's estimate that one inch of rainfall per year equals a daily average of 40,000 gallons per square mile. One-fourth of this, or 10,000 times $30=300,000$ gallons per day per square mile-640 acresreaching the aquifer. The intake area in square miles equals the flow per day divided by 300,000 gallons, the estimated daily intake; 2,678,400 divided by 300,000 equals 9, nearly. The supply area, then, need not be more than about nine square miles in extent. Professor Chamberlin made an estimate that the area of intake "need not exceed 400 acres in extent." His estimate was based upon "a discharge of $5,000,000$ gallons lowering the head five inches per day, and taking no account of inflow - the reservoir indicated has a clear surface of less than forty acres. A mixture of sand and gravel may easily contain one-fourth its volume in water, as may be shown by experiment; but assuming one-tenth, the upper stratum need not exceed 400 acres in extent." The total normal flow is a better basis for calculation than "Jumbo's" abnormal flow, as the former more nearly shows the real amount of water supplied to the aquifer. Professor" Carpenter's table of velocity of underground waters, given below, shows that the flow of underground water is very much slower than it has been supposed. The apparently rapid drawing off of the head after "Jumbo" broke loose, was due to the draining of the aquifer locally, and its inability to supply water fast enough on account of friction, rather than 
to drawing off the head, over the entire basin. The promptness with which the head began to rise-only about two months after Jumbo broke loose, and while still uncontrolled, appears to confirm this opinion. The head has lowered slightly, for the last four or five years, showing that the maximum number of wells has about been reached, and that many more wells, or letting those now drilled flow an unnecessary quantity of water, will reduce the head, injure all the wells in the area, and cause the wells on higher ground to cease flowing:

Besides the amount of water discharged from the runaway wells, thousands of gallons have been wasted by letting the wells run more than necessary. This has not yet become serious enough greatly to injure the wells. The deep wells drilled before Jumbo have since been useless, the water being too deep to be pumped easily.

Call mentions a well (No. 28), in Iowa county, range $80 \mathrm{~N}$, 12 W., section 12, with a flow of 1,500 gallons per hour. No other data are given. The location puts the well near Ladora. The writer has not heard of an artesian well near Ladora dug before 1891. The flow is about correct for the Belle Plaine vein. On his map of artesian wells in Iowa, Call locates a well (No. 108) about fifty miles west and north of the Belle Plaine area - the nearest in that direction. But this well is omitted from the continuation of the list of wells.*

The flow from the wells is not apparently affected by the rainfall. This is no doubt due to the slow movement of water in the aquifer. The head does vary, but not more than a few inches. It is difficult to keep an accurate record of the variation of the head. A decrease may be due to over draft instead of diminished head; or it may be in the individual well, so that the sources of error are too numerous to be guarded against, except in a very general way. Water flows much more readily through gravel than through sand, and where the aquifer is gravel below and sand above, it may be assumed

-Oall, Op. clt., p. 19, March, 1892. 
that the water flowing through the gravel rises to reinforce that in the sand above.

In the Belle Plaine artesian area, the irregularities of the aquifer account for certain irregularities of flow. At the edges, where the flow diminishes and the head of water becomes lower with unusual rapidity, as Nos. 58, 83 and 41, for instance, the aquifer is probably a thin vein of fine sand, with no underlying bed of coarse gravel near by. Probably a similar condition obtains at Marengo in No. 96. A group of wells towards the southern portion of the field, wells Nos. $143,142,118,152$, ought to have a head of about thirty-five feet, instead of six feet. The same thing occurs in a number of other wells in the southern portion of the field, Nos. 40,41, 89. In isolated wells of abnormally weak head, the weakness may be due to the well being not properly drilled, but in the group of four mentioned, Nos. 143, 142, 118, 152, which average about a quarter of a mile apart, improper drilling will not explain the diminisbed head. These wells are not so close together as to interfere with one another's flow, and they are ranged across the aquifer about at right angles to it. If these wells were ranged in a line parallel to the trend of the aquifer the case would be very different. Elevations being equivalent, in that case the well nearest the source of water would rob those more distant. The well nearest the source of water would flow with normal pressure, while the more distant wells would flow with a pressure less than normal. These wells are not near enough together to affect one another's flow. Improper drilling will not explain a group of wells acting in this way, so it seems reasonable to believe that their peculiar behavior is due to something in the source of supply. There is no doubt that the water comes from the Belle Plaine vein. It appear's reasonable to ascribe the diminished flow to some change in the character of the aquifer. The aquifer is changeable in thickness, varying from two feet to more than forty-six feet in thickness, and that within less than a mile. It is changeable in character also; varying from coarse 
gravel at the bottom in its thick places, to fine sand at the top. Suppose that the aquifer here is two feet of fine sand as in No. 98 , and that it persists as such for a balf mile to the northward; reference to the table will make it apparent that this state of things would easily account for the diminished flow and head.

The narrowing of the aquifer to about three miles, two miles to the northward towards the source of supply, probably diminishes the amount of water which flows into the portion of the field to the south and east of the constricted point. If this constriction affects any, it affects all the wells to the south and east of it, and influences them all alike. This may partly account for the fact that elevation of head diminishes faster proportionately, from Belle Plaine to Ladora, than from Vining to Belle Plaine. (See diagram No. 3.)

As to the part played by friction in the flow of underground water, Professor Carpenter of the Colorado experiment station has made interesting observations on the seepage or return waters from irrigation, from which he has prepared the following table.

TABLE' FOR FINDING APPROXIMATE VELOCITY OF FLOW OF WATER TBROUGH SOILS. BY PROE. L. G. CARPENTER:

Value of " $\mathrm{k}$ " in formula:
Velocity (in feet) =k times $\frac{\text { fall (in feet). }}{\text { distance (in feet). }}$

\begin{tabular}{|c|c|c|c|c|c|c|}
\hline \multirow[b]{2}{*}{ KIND OF MATERIAL. } & \multirow{2}{*}{ 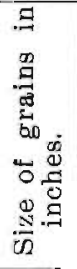 } & \multirow{2}{*}{ 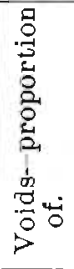 } & \multicolumn{4}{|c|}{$\begin{array}{l}\text { VALUE OF K TO GIVE VELOCITY } \\
\text { IN FEET. }\end{array}$} \\
\hline & & & $\begin{array}{l}0 \\
0 \\
0 \\
8 \\
0 \\
0 \\
\vdots \\
0 \\
01\end{array}$ & $\begin{array}{l}\dot{\vec{J}} \\
\dot{g} \\
\dot{8} \\
\dot{4}\end{array}$ & $\begin{array}{c}\vec{g} \\
\overrightarrow{8} \\
\overrightarrow{0}\end{array}$ & $\begin{array}{l}\stackrel{\tilde{J}}{\Phi} \\
\Phi \\
\dot{\Phi} \\
\dot{0}\end{array}$ \\
\hline Minute gravel & .08 & 0.41 & .024 & 86.47 & 2075.0 & 757.520 \\
\hline Coarse sand... & & 0.38 & .0026 & 9.33 & 224.0 & 81,730 \\
\hline Fine sand.. & .008 & 0.35 & .00047 & 1.69 & 40.5 & 14,777 \\
\hline Sandy soil. & $\ldots$ & 0.30 & .00022 & .79 & 18.9 & 6,897 \\
\hline Sandy clay. & & 0.25 & .00012 & .42 & 10 . & 3,7 \\
\hline Clay & & 0.20 & .00003 & .12 & 2.8 & 1,035 \\
\hline & $\cdots$ & . & .00008 & .295 & 7. & 2,5 \\
\hline
\end{tabular}

* Bulletin No. 33 on Seepage Waters, of the Colorado experiment station, Fort Collins, Ool. January. 1806, p. 47 . 
Illustration of use of Table: What distance will water pass through coarse sand in a year, witb fall of fifty feet per mile?

Here, fall divided by the distance is 50 divided by 5,280 , or 1-106; close enough, considering the approximation in the data, to call 1-100. If the sand averages 1-10-inch in diameter, without finer particles, it might be classed as minute gravel. Then from the table, " $k$," for velocity per year, is 757,520 , and distance is 757,520 times $1-100$, or 7,575 feet, or about $1 \frac{1}{2}$ miles.

If in coarse sand, same fall, distance in a year is 81,730 times 1-100 equals 817 feet. If movement is straight downward, the fall may be the same as the distance.

By this table, with a fall of 3.5 feet per mile, as in the Belle Plaine aquifer, in coarse sand, the water has a velocity of about 5.70 feet per year; in minute gravel, 53 feet per year. But in places where the vein is thick there is coarse gravel below, much coarser, indeed, than .08 of an inch in diameter. The largest grains are as much as .5-inch in diameter, and perhaps larger. In the coarse gravel the water moves with comparative freedom, the velocity may be as much as one mile per year. Professor Carpenter observes: "When the passage takes place through the interstices of the soil the movement" (of underground water) "is very slow, much slower than is ordinarily supposed by those first encountering. the subject. It is faster as the material is coarser. Where there are perceptible channels the movement may be relatively rapid."*

Referring to the table for finding approximate velocity of flow of water it is curious to note that, calculating that the water in the aquifer flows one mile per year, it would take eight years for water to flow from Vining to Belle Plaine, in a direct line, and nineteen years for water to flow from Vining to Ladora; seven years longer than the time since the wells were discovered! Or it will be 1905 before water which was

\footnotetext{
*"Bulletin Colorado Experiment Station," No. 33, p. 4.
} 
at Vining when Jumbo was struck in August, 1886, will flow from the wells at Ladora. If the Ladora wells about that time show an otberwise unaccountable decrease, it may be taken as a verification if the above. However, the effect of the drain may be minimized by (1) the constriction of the area southeast of Belle Plaine, (2) the apparent thinning out of the aquifer southwest of Koszta, and (3) the storage capacity of the thirty-foot vein at Ladora. The velocities given in the above table very graphically show (1) the vast importance of friction in the aquifer and (2) the variation produced by changes in the character of the latter.

The head of the Belle Plaine aquifer at Belle Plaine was 915 feet A. T. when first discovered. At present the head is 864 feet A. T. at the same point.

\section{THE SOURCE OF THE WATER.}

As has been mentioned above, the intake ground or catchment basin, from the general trend of the Belle Plaine area, appears to be towards the northwest. It is at whatever place or places, at present unknown, erosion of the glacial tills has exposed the Aftonian gravels. This locality need not be very far away. It may be near Wolf creek, in Tama county, but at present so little is known about the geology of this portion of the state that nothing definite can be said. The area of intake is not in the immediate vicinity to the north of Belle Plaine, as wells in the same aquifer have been drilled at Vining, eight miles to the northwest. The intake area is possibly in that direction, five or ten miles beyond Vining.

Professor Chamberlin says: "It is not, therefore, necessary to suppose any unusual subterranean source, either in area or kind, nor is it necessary to suppose a distant origin. The head is not greater than could be supplied by the country adjacent on the north, which is the probable supply ground. It is simply a flowing drift well, run rampant for want of control. It has its phenomenal feature in its magnitude, and its 
lesson in its expensive and destructive career through injudicious handling." $\%$

When Jumbo was struck some persons thought the aquifer was a solid vein of water, and were fearful lest this water escaping, the ground would cave in! "The well was supposed by many to tap an aqueduct leading from some large and distant body of water, but with such vagaries the reader will have little patience." $\nmid$ Some connected the lowering of level in certain lakes in northern Iowa, particularly Storm lake, with these wells. True, the lakes have lowered, but the wells have been in no way related to that phenomena.

"The life history of a lake, the conditions of its existence, show that it cannot be the reservoir of artesian water. If the depression which the lake occupies is due to secular lock decay, residuary clays, the produce of such decay, may cover the bottom with an impervious mantle. Though the depression may be due to other causes, it becomes an area of sedimentation on account of its relatively low relief. The floor is built up of layers which include, if they do not consist of, water-tight clays. Nor do lake beaches of sand, or sandy bottoms, afford subterranean outlet. Even if clayey layers do not occur immediately beneath, yet the pressure of the ground water from the higher levels of the surrounding land will usually prevent leakage. Such sundy layers thus become the conduits of sublacustrine springs, and replenish instead of deplete the water's of the lake. For reasons much the same it is not to be supposed that rivers contribute to artesian supply, except under special circumstances." + Mr. Calls: believed that the Cedar river was tapped below Waterloo, and the water conducted by a wide and deep channel to Belle Plaiue. If this were true the volume of the Cedar should diminish below that point. The writer has not found any evi-

\footnotetext{
*s sience, vol. VIII, p. 276 .

+Norton, op. olt, p. 352 .

:Norton. p. 159. See, also, Obamberlin, "Requistte and Qualifylng Conditions of Artesian Wells." Flith Ann. Rept. U. S. Geol. Surv., p. 132. (1885.)

sLow Weather and Crop Montbly, March, 1892, p. $\%$.
} 
dence confirming this. Mr. Call suggests, also, that there may be "at least two, and possibly three, water-bearing strata, one of which is coincident with the forest bed of Iowa." There is, however, only one aquifer penetrated in the Belle Plaine wells. " "Certain it is," says he, "that some unusual and abundant water supply prevails in that section. The rainfall is not above the mean of the state, and no other subterranean source seems probable." These arguments have been sufficiently refuted above.

CHEMISTRY OF THE WATER.

ANALXSIS OF THE BELLE PLAINE ARTESIAN WATER.

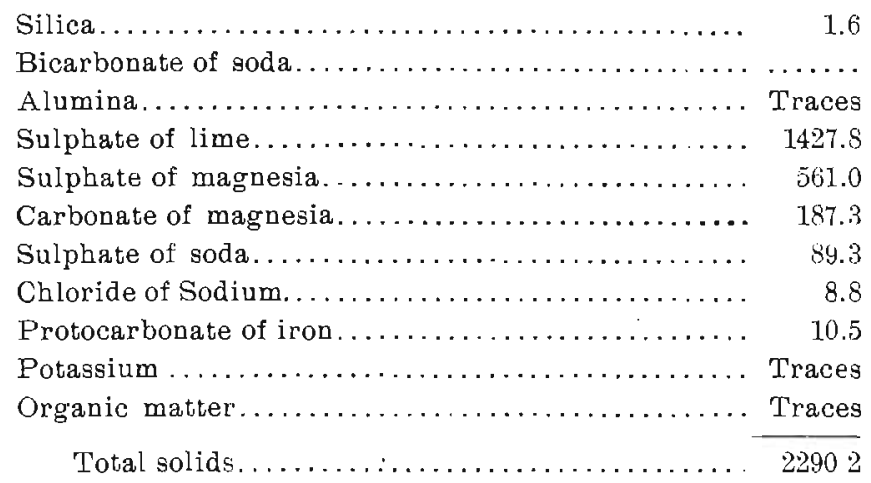

This analysis was made by Prof. L. W. Andrews of the State university.

The water from these wells is about as heavily charged with mineral matter as any artesian water in Iowa. The water leaves a sediment from the lime salts, which incrusts the pipes, and has a red stain from the iron. At the same time, it consumes ordinary galvanized pipe to a shell, in three or four years. The large amount of mineral water in solution does not seem to lessen. No analysis has been made since 1886, so that the present and past amount of mineral cannot be compared. The indications, however, are that thel'e has been little, if any, change. The water consumes pipes just as rapidly, and deposits sediment and stain just as thickly and as quickly as at first. Considering the vast 
quantity of water which has flowed from the wells, the persistence of the mineral in solution may be explained by the slow flow of the water through the aquifer.

It is not necessary to suppose any extraordinary or unusual source for the mineral matter in the water. The glacial till is made up of rock grindings which can easily supply the minerals found. These are the same as in other Iowa artesian wells, and are directly or indirectly derived from the constituent and accessory minerals of soils and rocks.* The analyses of several artesian wells are compared below. The analyses are from Call's article.

\begin{tabular}{|c|c|c|c|c|c|c|}
\hline $\begin{array}{c}\text { QUANTITATIVE } \\
\text { ANALYSES-PARTS TO } \\
\text { 1,000,000 PARTS } \\
\text { WATER. }\end{array}$ & 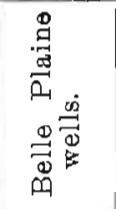 & 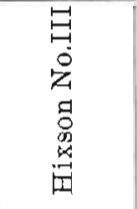 & 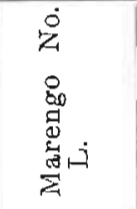 & 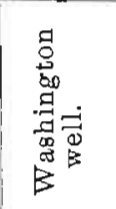 & 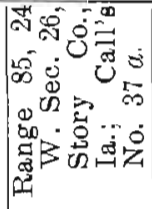 & 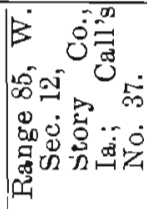 \\
\hline te & $1,427.8$ & 284 & 295.990 & 246.95 & & \\
\hline 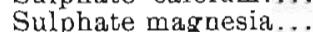 & 661.0 & & 10 & & & \\
\hline Chloride & 8.8 & 22662 & 33.252 & 9132 & & 1.660 \\
\hline iron. & 10.5 & 37.129 & 9.313 & & & \\
\hline$\ldots$ & 89.3 & 151.997 & 338.351 & $5+7.90$ & & \\
\hline a.. & 183.3 & & & 153.67 & 27.681 & 118.301 \\
\hline Bica & & 398 & & & & \\
\hline Sil & 1.6 & 38.122 & 6.405 & ${ }^{*} 35.14$ & 26.083 & Trace \\
\hline $\mathrm{Al}$ & Trace & Trace & & 17.60 & $\ldots$ & $\ldots \ldots \ldots$ \\
\hline & Trace & & & 1800 & & \\
\hline $\mathrm{Ca}$ & & b51. & 436.5 & 88.20 & .621 & .064 \\
\hline Bic & & & 1 & & & $\ldots$ \\
\hline & $\cdots$ & 53.014 & $\ldots$ & $\cdots$ & . &. \\
\hline & & Trace & & & & \\
\hline $\mathrm{m}$ & Trace & 90 & & & & $\cdot$ \\
\hline Sulphate & & 89 & & Trace & & \\
\hline & & & & Trace & & \\
\hline & & & & 17.50 & & \\
\hline & & & & & 6.243 & \\
\hline So & & & & & 118.949 & 43.502 \\
\hline Ferric ox & & & & & & 950 \\
\hline Alumint & & & & & & 900 \\
\hline Total & $2,290.2$ & $1,941.179$ & $2,734.348$ & $1,142.24$ & $\left\{\begin{array}{r}486.577 \\
(490.459)\end{array}\right.$ & $\begin{array}{r}376.489 \\
(375306)\end{array}$ \\
\hline
\end{tabular}

*Ana insoluble resiaue.

A comparison of the analyses shows that the Belle Plaine water contains about the same minerals, and in about the proportion, as other artesian wells. The Belle Plaine water *Norton, op. cit., p. 363.

$44 \mathrm{G}$ Rep 
carries but little more calcium carbonate, and has less total solids than the Marengo well, which is not a well in drift. The pipe-consuming qualities of the water shortens the life of the weaker wells. The temperature of the water remains fixed at about $52 \mathrm{~F}$. the year round.

From examination of the analyses of the Belle Plaine water, its therapeutic or medicinal value, or want of value, is very apparent. The most extravagant claims bave been made as to the value of this water in curing almost every human ailment, from rheumatism to dyspepsia. One physician says that the water has mild laxative and diuretic, and slight alterative value. Another physician says that "the water possesses very little, if any, therapeutic value; on the contrary, it is highly injurious in certain conditions of the kidneys. Persons having weakness of the kidneys or bladder trouble cannot use the water at all without suffering bad effects. There are those who claim that the water has performed marvelous cures for them, but the fact must be considered that their ailments have been more mental than physical."

The food taken into the body supplies sufficient mineral matter, so it is unnecessary, and even injurious, to drink water heavily charged with mineral matter, which the Belle Plaine water is. It cannot then be said that the Belle Plaine artesian water has any therapeutic value, or is even a good drinking water. That mineral water is best which contains the least mineral. Pure rain water, or better, distilled water, is the best water for drinking purposes. Several inexpensive and very satisfactory stills are now on the market.

It has been claimed that the water is "magnetic," and that "a knife blade held in this water a few seconds would become charged strong enough to pick up a pin."* The writer has experimented by suspending a knife blade in the running water from a few seconds to half a day, but in no case would the blade, when carefully dried, attract a pin, or even a

\footnotetext{
*History op Jumbo, p. 24.
} 


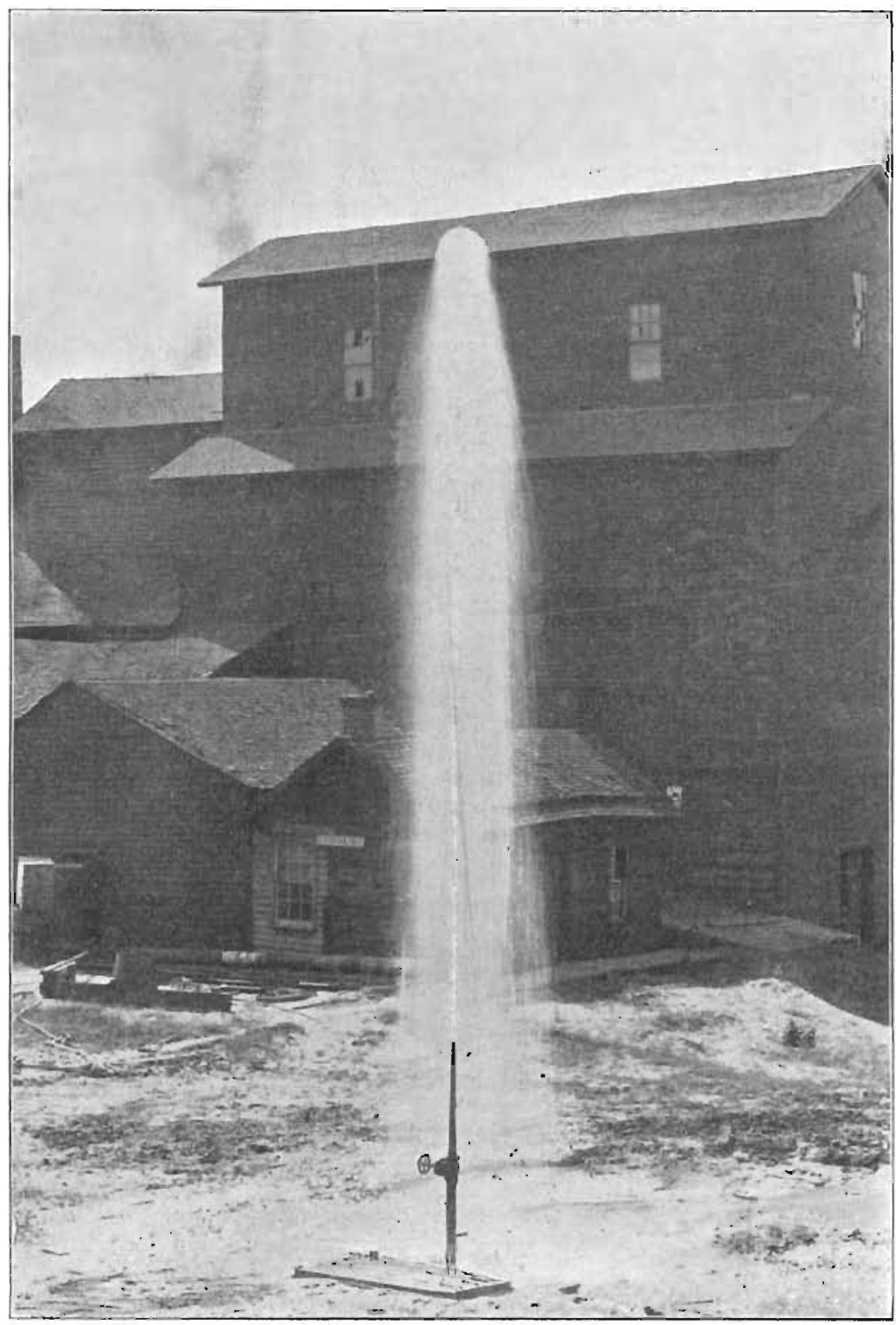

Artesian well, at the corner of Flrst and Maple streets, Belle Plalne, Iow $\mathrm{n}, \mathrm{Ju}$ ly, 1888. 
lowa Ceological Surrey

$$
\begin{array}{r}
\text { V. } \\
1898
\end{array}
$$

Bhan pryefores 7.555 
needle. The wet blade, however, will "pick up" a pin beautifully, but not by magnetism. This fact may explain the numerous so-called "magnetic" waters.

\section{USES OF THE WATER.}

It has been shown that the Belle Plaine artesian water is of little or no value as a medicinal or drinking water. The analysis shows it to be unfit for steaming or manufacturing purposes. Its pipe-consuming quality, and its sediment and unfitness for culinary, household or manufacturing purposes, makes it unavailable for eity waterworks.

It is not necessary to use the water for irrigation, and the volume is not sufficient, except for irrigation on a small scale. Neither is the volume sufficient to furnish power for manufacturing purposes. Hon. J. J. Mosnat has attached a small waterwheel to a weak-flowing well (number 62), and uses the power for pumping water to supply his residence. The one use of the water is for stock. Nearly every farm in the area has one or more wells. After cattle become accustomed to the peculiar taste of the water they are said to prefer it to other water. Indeed they appear to thrive on it. This has been the principal use of the water since the vein was first discovered.

\section{WELL RECORDS.}

Below are given the records of a large number of the wells in the area. In Table I is the geological section of certain of the wells penetrating the rock. 
TABLE I.

SECTIONS OT WELTS.

WELL NO. A

\begin{tabular}{|c|c|c|c|c|}
\hline & DESCRIPIION OY' SIRATA. & 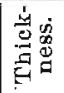 & $\frac{1}{ \pm}$ & $\begin{array}{l}\text { OEOLOQICAL } \\
\text { FORMATION. }\end{array}$ \\
\hline & 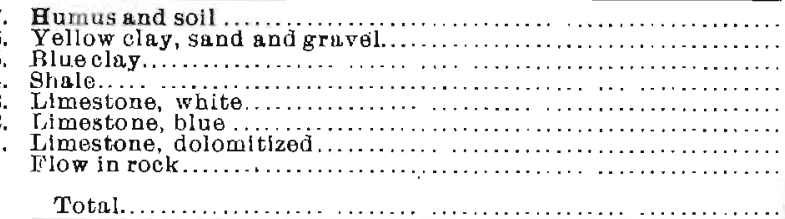 & $\begin{array}{r}4 \\
33 \\
149 \\
30 \\
6 \\
12 \\
\cdots \\
\cdots \\
\cdots \\
233 \\
\end{array}$ & $\begin{array}{c}793 \\
789 \\
756 \\
608 \\
578 \\
572 \\
\ldots \ldots \\
\ldots \ldots\end{array}$ & $\begin{array}{l}\text { Recent. } \\
\text { Loess. } \\
\text { Kansan. } \\
\text { Oarboniferoug, } \\
\text { Kovonian. }\end{array}$ \\
\hline
\end{tabular}

WELL NO. O

\begin{tabular}{|c|c|c|c|}
\hline 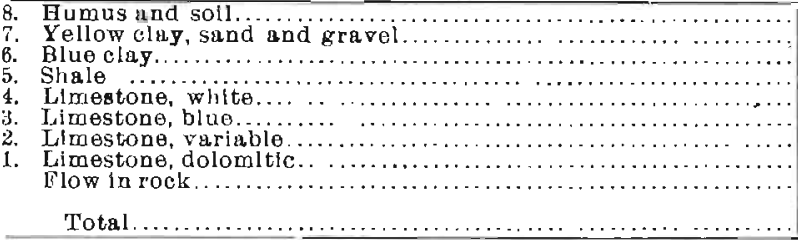 & 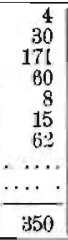 & $\begin{array}{l}820 \\
816 \\
786 \\
615 \\
555 \\
547 \\
552 \\
470\end{array}$ & $\begin{array}{l}\text { n. } \\
\text { aj ferous }\end{array}$ \\
\hline & & & \\
\hline 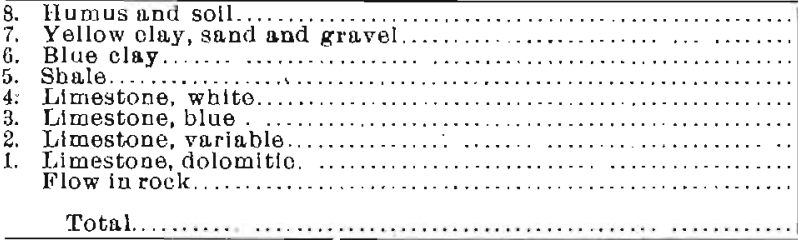 & $\begin{array}{r}4 \\
30 \\
174 \\
80 \\
8 \\
12 \\
64\end{array}$ & 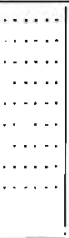 & $\begin{array}{l}\text { Recent. } \\
\text { Loess. } \\
\text { Kansan. } \\
\text { Uurboniferous } \\
\text { Devonlan. }\end{array}$ \\
\hline
\end{tabular}

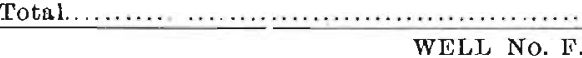

\begin{tabular}{|c|c|c|c|}
\hline 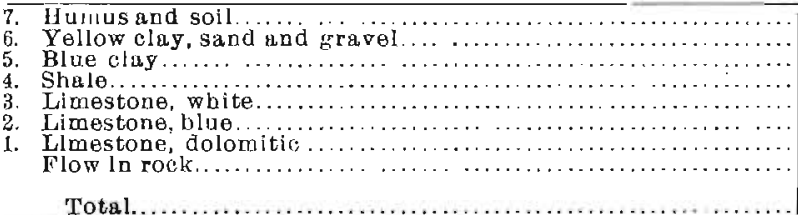 & $\begin{array}{r}5 \\
30 \\
165 \\
100 \\
8 \\
12 \\
\cdots \\
\cdots\end{array}$ & $\begin{array}{l}897 \\
802 \\
792 \\
627 \\
527 \\
519 \\
507\end{array}$ & $\begin{array}{l}\text { Recont. } \\
\text { Loess. } \\
\text { Kunsan. } \\
\text { Oarboniferous. } \\
\text { Devonlan. }\end{array}$ \\
\hline
\end{tabular}

Total.

WELL NO. L.

\begin{tabular}{|c|c|c|c|}
\hline 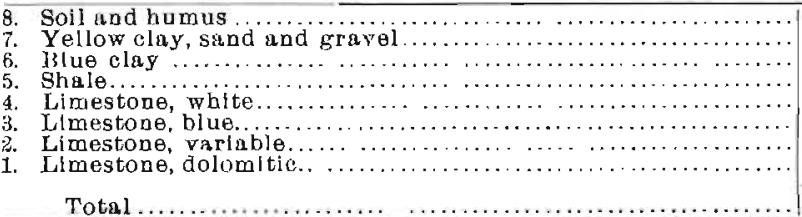 & $\begin{array}{r}5 \\
20 \\
58 \\
50 \\
12 \\
15 \\
205 \\
\\
\\
\end{array}$ & $\begin{array}{l}745 \\
740 \\
7 \% 0 \\
6162 \\
612 \\
600 \\
585 \\
380\end{array}$ & $\begin{array}{l}\text { Recont. } \\
\text { Loess. } \\
\text { Kansun } \\
\text { Oarbonlferous } \\
\text { Devonian. }\end{array}$ \\
\hline
\end{tabular}

WELL NO. M.

\begin{tabular}{|c|c|c|c|}
\hline 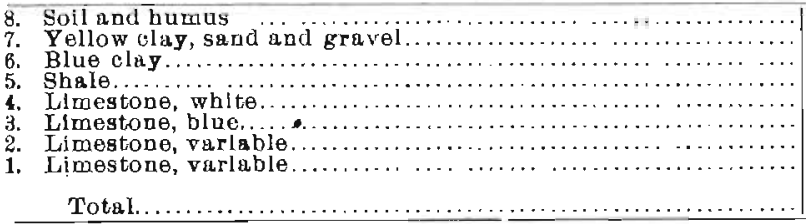 & $\begin{array}{r}5 \\
20 \\
58 \\
80 \\
12 \\
15 \\
226 \\
\cdots \\
\\
416 \\
\end{array}$ & $\begin{array}{l}759 \\
754 \\
734 \\
678 \\
596 \\
584 \\
569 \\
343\end{array}$ & $\begin{array}{l}\text { Recent. } \\
\text { Loess. } \\
\text { Kansan. } \\
\text { Oarboniferous. } \\
\text { Devonlan. }\end{array}$ \\
\hline
\end{tabular}


TABLE II.

LIST OF ARTESIAN WELLS OF THE BELLE PLAINE AREA.

\begin{tabular}{|c|c|c|c|c|c|c|c|c|c|c|c|}
\hline & & & & & & & & & FLO & & \\
\hline $\begin{array}{l}\dot{\bar{z}} \\
\tilde{g} \\
\dot{0} \\
\dot{0} \\
\dot{z}\end{array}$ & COUNYY. & TOWNSHIP. & 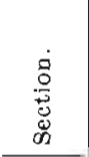 & OWNER. & 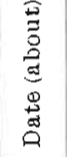 & $\mathrm{DCQ} B Y-$ & 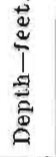 & 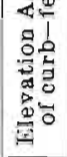 & 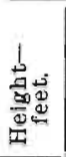 & 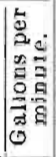 & REMARKS. \\
\hline 1 & Benton ... & Iowa. & $10 \mathrm{SE}$ & Willinm and J. Lester. & 1882 & & 345 & & -100 & & Not used now. \\
\hline$\stackrel{2}{3}$ & Benton $\ldots$ & Iowa. & $8 \mathrm{NE}$ & S. L Bardwell ........... & 1882 & & $\begin{array}{l}260 \\
305\end{array}$ & $\cdots \cdots$ & $\begin{array}{l}-25 \\
-125\end{array}$ & $\cdots$ & $\begin{array}{l}\text { Nut used now. } \\
\text { Not used now. }\end{array}$ \\
\hline & Benton .... & frourth St betwo Maplo & & s. worliey ............ & & & & & & & Sol used now. \\
\hline & & Plaine................. & & Company & 1880 & & 303 & 918 & -51 & $\cdots$ & Noti used now; sand \\
\hline 5 & Benton .... & Fast First St. B. Plaine. & & Hilton Bros & 1880 & Weir \& Sons. & 215 & 836 & 53 & . . & $\begin{array}{l}\text { Overewen } \\
\text { First flow. }\end{array}$ \\
\hline & Benton ... & Cor. Hirst and Beech Sts., & & Company & 1886 & & 225 & 846 & 22 & $\cdots$ & \\
\hline 7 & Benton .... & $\begin{array}{l}\text { Cor. First and Maple Sts., } \\
\text { Belle Plaine. }\end{array}$ & & Company & 1880 & & 228 & 848 & 19 & 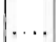 & Sand velú 5 ft. 3 In. \\
\hline 8 & Benton & Foundry, West Washing- & & Palmer Bros. & $18 \times 8$ & Polmer Bros & & $=30$ & 37 & & \\
\hline 2 & Benton & $\begin{array}{l}\text { ton St., Belle Plaine..... } \\
\text { Beech st., Belle Plaine.. }\end{array}$ & & Company.... & $\begin{array}{l}1886 \\
1886\end{array}$ & Palmer Bros. & 193 & 811 & 54 & $\cdots$ & The famous Jumbo. \\
\hline 10 & $\begin{array}{l}\text { Beaton } \\
\text { Tama. }\end{array}$ & $\begin{array}{l}\text { East First St., B. Plaine. } \\
\text { Salt Creek ............... }\end{array}$ & $12 \mathrm{SE}$. & $\begin{array}{l}\text { Belle Plaine Canning factory. } \\
\text { G. W. Snyder. }\end{array}$ & $\begin{array}{l}1886 \\
1885\end{array}$ & & $\begin{array}{l}215 \\
197\end{array}$ & 838 & 32 & .. & Fllled up. \\
\hline 12 & Tama.. & 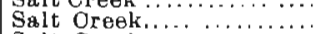 & $15 \mathrm{SE}$ & Willey ... & 1886 & & 200 & & 40 & & \\
\hline 3 & Tama & Snlt Oree & $23 \mathrm{NW}$ & Richard Turabull & $188 \%$ & & 143 & & $\lim _{20}$ & $\cdots$ & \\
\hline 14 & Tama & Salt Creek. & $25 \mathrm{NW}$ & Richard Turabull & 1888 & 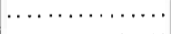 & 218 & $\cdots$ & 32 & $\cdots$ & \\
\hline 10 & Cama. & 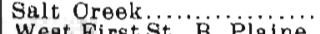 & $15 \mathrm{SW}$ & John Strubble & 1887 & Wej \& Sins & 200 & .. & 44 & $\cdots$ & Not used now \\
\hline 17 & Benton & West First St., B. Plalne. & $22 \mathrm{NW}$ & Fremont hote & $\begin{array}{l}1886 \\
1 \times 87\end{array}$ & & 106 & $\ldots . .$. & 80 & $\cdots$ & \\
\hline 18 & Tama & $\begin{array}{l}\text { West First St. B. Plaine. } \\
\text { West Wirst St. B. Plaine. }\end{array}$ & $9 \mathrm{NW}$ & N.Zemun. & $188_{i}$ & & 218 & $\cdots$ & 40 & & \\
\hline 19 & Tama. & West First St., B. Plaine. & $5 \mathrm{NE}$ & Mussel & 1887 & & 220 & ... & 30 & . & \\
\hline 20 & Bention & Daseball park, B. Plalne. & & Oompang & 1888 & & 210 & .. & 37 & $\cdots$ & \\
\hline 21 & Tama & Salt Oreek .................... & $13 \mathrm{NE}$ & Frank Kerner. & 1887 & $\ldots \ldots \ldots \ldots \ldots$ & 170 & & 75 & $\cdots$ & \\
\hline 23 & I'tama & Salt Creek. & $13 \mathrm{sW}$. & S. Marnesona & 1888 & & $160^{\circ}$ & . & 80 & $\cdots$ & \\
\hline 24 & Tama & Salt Ureek. & $11 \mathrm{SE}$. & H. B. Edwards. & 1889 & & 218 & ..... & 30 & ... & \\
\hline 25 & Tama & Sult Croek. & $2 s W$. & Joseph Petrizelka & 1889 & & 230 & & $\frac{20}{20}$ & $\cdots$ & \\
\hline 26 & Tama & Salt Oreok. & $24 \mathrm{NW}$ & J. F. Ealy & 1088 & …...... & 172 & “ & $\begin{array}{l}75 \\
80\end{array}$ & $\cdots$ & \\
\hline 20 & Tama & $\begin{array}{l}\text { Salt Oreek..... } \\
\text { Salt Oreek.... }\end{array}$ & $\$ \mathrm{NE}$ & Joseph Sarda & $\begin{array}{l}1086 \\
1886\end{array}$ & & 360 & & -110 & $\cdots$ & Highest point in the \\
\hline 30 & Tama & Salt Oreek..... & $25 \mathrm{SE}$ & Alex White & 1888 & $\ldots \ldots \ldots$ & 164 & & 80 & $\cdots$ & \\
\hline & Tama & Salt Ore & $25 \mathrm{NE}$ & & & & & 760 & & & \\
\hline
\end{tabular}


TABLE II-OONTINUED.

\begin{tabular}{|c|c|c|c|c|c|c|c|c|c|c|c|}
\hline \multirow[b]{2}{*}{ 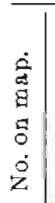 } & \multirow[b]{2}{*}{ COENTY. } & \multirow[b]{2}{*}{ TOWISEIP. } & \multirow[b]{2}{*}{ 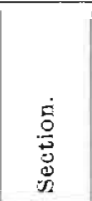 } & \multirow[b]{2}{*}{ OWNER. } & \multirow[b]{2}{*}{ 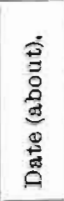 } & \multirow[b]{2}{*}{ DCG BY- } & \multirow[b]{2}{*}{$\begin{array}{l}0 \\
\stackrel{0}{0} \\
\stackrel{0}{0}\end{array}$} & \multirow{2}{*}{ 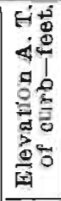 } & \multicolumn{2}{|c|}{ FLOW. } & \multirow[b]{2}{*}{ REMARES. } \\
\hline & & & & & & & & & 起 & 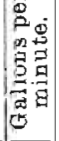 & \\
\hline & Benton & Krane (Irvlng). & $31 \mathrm{SW}$ & Mrs. Jobnson... & 1888 & & 220 & & 30 & $\ldots$ & \\
\hline 33 & Benton .... & Iowa. & $22 N W$ & A. H. Hardy... & 1886 & & 243 & $\cdots$ & 10 & 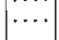 & Not fowing now \\
\hline 35 & Benton ..... & Iowa. & $23 \mathrm{NE}$ & H. Webrman. & 1896 & & 230 & & 12 & $\cdots$ & LOU 110 W \\
\hline $\begin{array}{l}36 \\
33\end{array}$ & Benton .... & Iowa. & $26 \mathrm{NW}$ & Willam Shriver. & 1886 & & $\begin{array}{r}230 \\
200\end{array}$ & ... & 12 & $|\ldots|$ & \\
\hline $\begin{array}{l}37 \\
38\end{array}$ & $\begin{array}{l}\text { Benton } \\
\text { Benton }\end{array}$ & $\begin{array}{l}\text { lowa. } \\
\text { Iowa. }\end{array}$ & $\begin{array}{ll}28 \\
33\end{array}$ & Ohrist Abreas. & $\begin{array}{l}1887 \\
1885\end{array}$ & & $\begin{array}{l}200 \\
170\end{array}$ & & $\begin{array}{l}20 \\
80\end{array}$ & $\cdots$ & \\
\hline 39 & Benton & Iowa. & $34 \mathrm{NW}$ & Mrs M. O.Gulnn & 1885 & Palouer Bros & 218 & & 29 & $\cdots \cdot \mid$ & \\
\hline & Benton & Iowa.. & $34 \mathrm{SE}$ & E. Trueblood.. & 1888 & 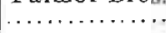 & 110 & & 18 & 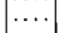 & \\
\hline 41 & Benton & Towa. & $35 \mathrm{SW}$. & Joseph Young. & 1888 & & 125 & .. & 20 & $\cdots$ & \\
\hline 42 & Bencon & Iowa. & $28 \mathrm{NE}$ & Theresa Beal & 1867 & & 240 & & 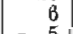 & $\ldots$ & \\
\hline 43 & Benton & Towa. & $20 \mathrm{NE}$ & Theres Beal & 1887 & .... & 252 & & $\begin{array}{r}-5 \\
-62\end{array}$ & $\cdots$ & \\
\hline $\begin{array}{l}4 \\
45\end{array}$ & $\begin{array}{l}\text { Benton } \\
\text { B. nton }\end{array}$ & $\begin{array}{l}\text { Soutb Oak St, B. Plaine } \\
\text { Iowa }\end{array}$ & $32 \mathrm{SE}$ & T. P Hunson & $\begin{array}{l}1888 \\
1889\end{array}$ & $\cdots$ & $\begin{array}{l}134 \\
160\end{array}$ & $\cdots$ & $\begin{array}{l}68 \\
87\end{array}$ & $\cdots \cdot \mid$ & \\
\hline 46 & Benton. & Iowa... & $17 \mathrm{SW}$ & E. B. Wright. & 1884 & & 205 & & & $\cdots$ & Not used now. \\
\hline 17 & Bentun & Iowa., & $10 \mathrm{NW}$ & E. B. kdwards & 1888 & & 180 & 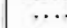 & 80 & $\ldots$ & \\
\hline & Benton & Iowa. & $18 \mathrm{sW}$ & Gouldy and Bruner line & 1887 & 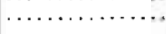 & 210 & ….. & 35 & $\cdots \cdot \mid$ & \\
\hline 年 & Bentan... & $\begin{array}{l}\text { lowa } \\
\text { lowa. }\end{array}$ & $\begin{array}{l}7 \mathrm{SE} \\
18 \mathrm{NW}\end{array}$ & H. Blekford. & 1858 & 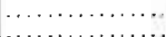 & 197 & $\cdots \cdot \cdot$ & $\frac{18}{45}$ & $\cdots$ & \\
\hline 51 & Taman... & Salt dreek. & $16 \mathrm{NE}$. & $\begin{array}{l}\text { U. W. Gouldy.... } \\
\text { Anthrow Mussel }\end{array}$ & & & 206 & $\ddot{8} 24$ & 40 & $\cdots$ & \\
\hline 52 & Timar & Sult Oreek. & ......... & - Stickler. & & & 208 & 826 & & . & Not runntag now. \\
\hline 03 & Tama & salt Creek. & $16 \mathrm{SE}$. & Wlikes & 1891 & & 166 & 785 & 60 & & \\
\hline & Tamu & Salt Creok. & $4 \mathrm{SE}$ & F. Posekany. & & & 204 & 822 & 45 & $\cdots$ & \\
\hline D. 56 & Tama & Salt Creek. & $4 \mathrm{YE}$ & Joseph Skarda & 1891 & & 247 & 885 & & $\cdots$ & Not running now. \\
\hline 57 & Tama. & Salt Creek. & \begin{tabular}{|r|r|}
$4 N \mathrm{NE}$ \\
$\mid$
\end{tabular} & Joseph Skarda & 1894 & & 245 & 863 & 2 & $\cdots$ & \\
\hline 58 & Tama. & Salt Oreek. & $27 \mathrm{SW}$ & D. Wilcox.. & 1890 & & 200 & 819 & 4 & $\cdots$ & Very weak flow. \\
\hline & Benton...... & $\begin{array}{l}\text { Salt } \\
\text { Nortb side schoolbouse }\end{array}$ & & O. Vickery & 1814 & & 201 & 819 & 48 & & \\
\hline & & Belie Plaine.............. & & School district....... & 1895 & & 312 & 804 & -18 & $\cdots$ & Water-bearing rein, \\
\hline & & & & & & & & & & & gravel-water atatit \\
\hline 61 & Benton & North Maple St,,B. Plaine & & J.J. Mosue & 1891 & & 243 & 861 & & & Not running now. \\
\hline & Benton & North Maples & & J.J Mosn & 1896 & & 243 & 881 & 316 & & \\
\hline 63 & Benton .. & Finir grounds, B & $12 \mathrm{SF}$ & Big Four Falr & $\begin{array}{l}1893 \\
1894\end{array}$ & $\cdots$ & 218 & $\begin{array}{l}838 \\
843\end{array}$ & $\begin{array}{l}29 \\
50\end{array}$ & * & \\
\hline 65 & Tаша .. & $\begin{array}{l}\text { Salt Creek. } \\
\text { Salt Creek. }\end{array}$ & $24 \mathrm{Ky}$ & $\begin{array}{l}\text { G. Wh snyder } \\
\text { S. Donnivar. }\end{array}$ & 1888 & & 166 & 785 & 81 & & \\
\hline 66 & Tuma & Salt Creek. & $11 \mathrm{SE}$. & O. Mac Intire & 1894 & & 218 & 836 & 29 & & \\
\hline 67 & Tama & Salt Oreek. & 13.511 & L. Prill. & $189 \mathrm{~L}$ & & 200 & 818 & 47 & & \\
\hline 68 & Tawa & Salt Oreek. & O SE. & Charles D & & & 200 & & 50 & $\cdots$ & \\
\hline 69 & Tama & Salt Creek. & 2sir. & M. Blaha, Jr. & 1865 & & 218 & . & $\begin{array}{l}35 \\
0 \\
0\end{array}$ & $\cdots$ & \\
\hline & Tama... & shit Ureek... & $3 \mathrm{NE}$ & 11. Drorak & & & 239 & & & & \\
\hline
\end{tabular}



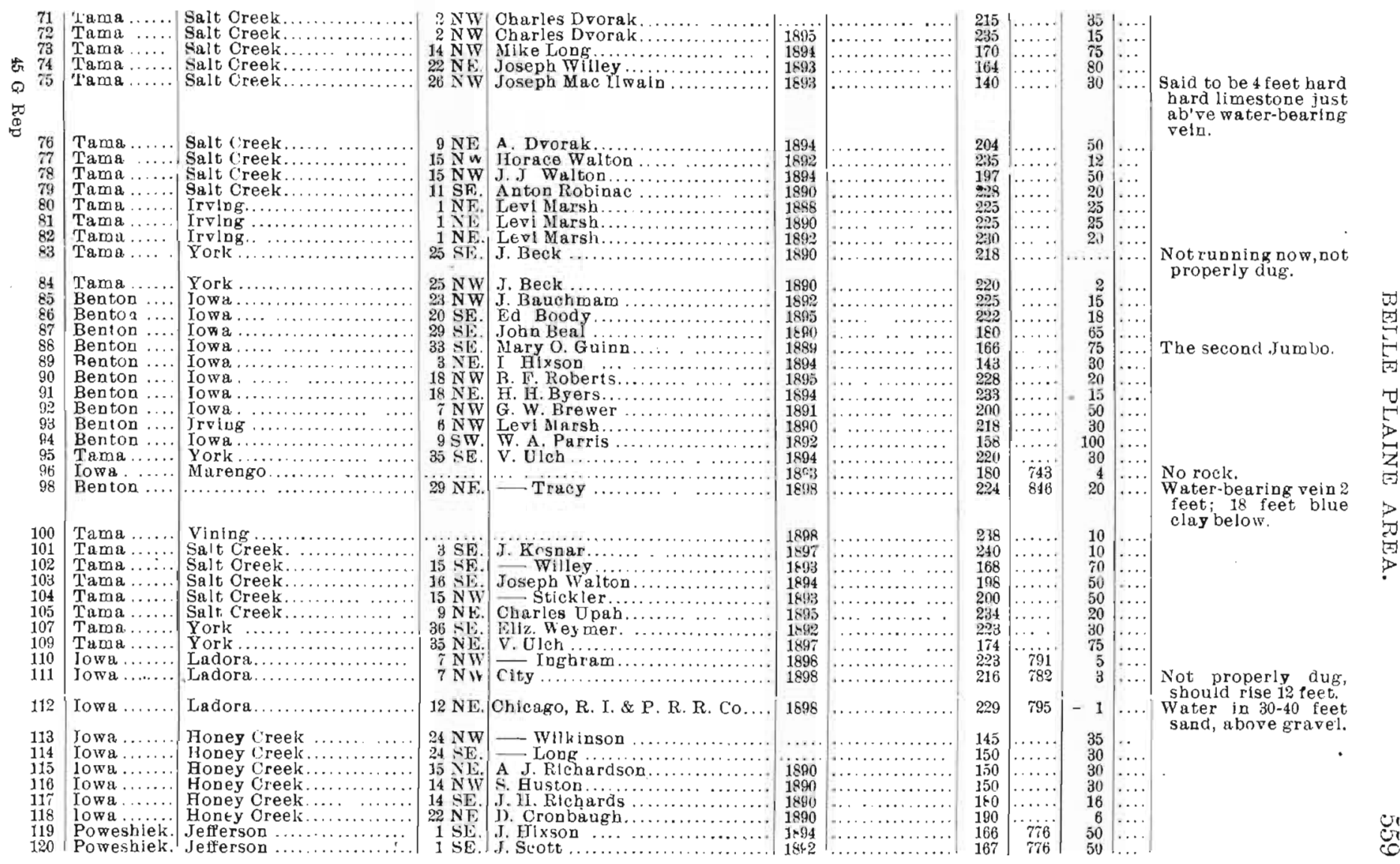
TABLE No. II-Contrnued.

\begin{tabular}{|c|c|c|c|c|c|c|c|c|c|c|c|}
\hline & & & & & & & & & FLO & & \\
\hline $\begin{array}{l}\text { 夏 } \\
8 \\
0 \\
\dot{0}\end{array}$ & COLNTX. & TOWNSEIP. & $\begin{array}{l}\text { o. } \\
\text { D. } \\
\text { D. }\end{array}$ & OWNER & 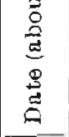 & $\mathrm{DEG} B \mathrm{BY}-$ & 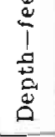 & 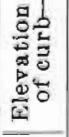 & 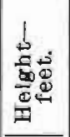 & 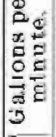 & BEMARKS. \\
\hline 121 & Poweshiek & Jefferson ..... & $18 \mathrm{w}$ & F. Fonuenek .......... & 1822 & $\ldots \ldots \ldots$ & 236 & 946 & & .. & because \\
\hline 122 & Iorsa. & Honey Creek. & $6 \mathrm{NW}$ & L. $\mathbf{F u h l}$ & 1891 & …... & 160 & 770 & 60 & & \\
\hline 4 & $\begin{array}{l}\text { lowa. } \\
\text { lowa. }\end{array}$ & $\begin{array}{l}\text { Honeg Creek. } \\
\text { Honey Creek }\end{array}$ & $\begin{array}{l}6 \mathrm{NE} \\
\mathrm{TNE}\end{array}$ & 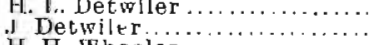 & $\left|\begin{array}{l}1891 \\
1891\end{array}\right|-200$ & & 200 & $\begin{array}{l}810 \\
810\end{array}$ & $\begin{array}{l}20 \\
20\end{array}$ & $\ldots$ & \\
\hline 126 & $\begin{array}{l}\text { Jowa. } \\
\text { Iowa. }\end{array}$ & $\begin{array}{l}\text { Honcy Creek. } \\
\text { Honey Ureek. }\end{array}$ & $\begin{array}{ll}6 \text { BSE. } \\
5 \text { SEE }\end{array}$ & $\begin{array}{l}\text { H. H. Wheel } \\
\text { L. B. Anders }\end{array}$ & $\left|\begin{array}{l}11991 \\
1 \leqslant 92\end{array}\right|-20$ & & $\begin{array}{l}164 \\
220\end{array}$ & $\begin{array}{l}7740 \\
830\end{array}$ & 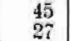 & $\cdots$ & \\
\hline $\begin{array}{l}128 \\
120 \\
1 \geq 4\end{array}$ & Iona. & $\begin{array}{l}\text { Honey Creek. } \\
\text { Honey Creek. }\end{array}$ & $\begin{aligned} 9 \mathrm{NW} \\
10 \mathrm{SW}\end{aligned}$ & $\begin{array}{l}\text { B. Bradford. } \\
\text { II Washburn }\end{array}$ & $\begin{array}{l}1890 \\
1890\end{array}$ & $\cdots$ & $\begin{array}{l}130 \\
160\end{array}-2-20$ & $\begin{array}{l}760 \\
790\end{array}$ & $\begin{array}{l}60 \\
30\end{array}$ & $\cdots:$ & ' \\
\hline & $\begin{array}{l}\text { Iowa } \\
\text { Iowt. }\end{array}$ & $\begin{array}{l}\text { Honey Creek. } \\
\text { lloney Cruek. }\end{array}$ & $\begin{array}{l}33 \mathrm{BE} \\
13 \mathrm{BW}\end{array}$ & IV. Border... & 1888 & & $\begin{array}{l}340 \\
140\end{array}$ & 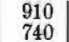 & $\begin{array}{r}98 \\
50\end{array}$ & .... & \\
\hline $\begin{array}{lll}103 \\
133\end{array}$ & $\begin{array}{l}\text { Tama: } \\
\text { Tama. }\end{array}$ & $\begin{array}{l}\text { Yorli, Vinlng } \\
\text { Viuing ... }\end{array}$ & $20 \mathrm{NE}$ & $\begin{array}{l}\text { Stock yards } \\
\text { Gity .......... }\end{array}$ & 1896 & & $\frac{217}{230}$ & $\begin{array}{l}858 \\
875\end{array}$ & $\begin{array}{l}40 \\
40 / 2 \\
3 / 2\end{array}$ & $\mid \begin{array}{c}\cdots \\
\cdots\end{array}$ & much \\
\hline 134 & Tama. & Vlaing $\ldots$ & $20 \mathrm{NE}$. & City. & & & 234 & 879 & & & $\begin{array}{l}\text { dug. } \\
\text { old wells, not now }\end{array}$ \\
\hline 195 & Tama. & $\operatorname{Vin} \log \ldots$ & $20 \mathrm{NE}$ & Citg ....... & & & 234 & 879 & & & $\begin{array}{l}\text { flowing } \\
\text { Old weils, not now }\end{array}$ \\
\hline 136 & Fowe: & Jefferson & $1 \mathrm{NW}$ & Harry & 1893 & & 215 & & 32 & $\ldots$ & \\
\hline & & & & $\begin{array}{l}\text { Ed. } \\
\text { (1) }\end{array}$ & $\begin{array}{l}1893 \\
1893\end{array}$ & & 210 & & $\begin{array}{ll}37 \\
14\end{array}$ & 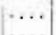 & \\
\hline 139 & Powesblek. & Jefferson & $12 \mathrm{NW}$ & W. Foster & 1890 & & 540 & $\cdots$ & 7 & $\cdots$ & \\
\hline 141 & $\begin{array}{l}\text { lama } \\
\text { Benton }\end{array}$ & & $21 \leqslant \mathrm{~F}$ & Alber & 1898 & & 202 & & 25 & & \\
\hline $\begin{array}{l}142 \\
143\end{array}$ & Iowa. & Honey Oreek. & $\begin{array}{ll}22 \mathrm{NE} \\
0 \mathrm{~N}\end{array}$ & J Combaugh.... & & & $\begin{array}{l}150 \\
100\end{array}$ & & 6 & $\cdots$ & \\
\hline 144 & Tam: & York, Elbe & $\tilde{1}_{13} \mathrm{NW}$ & City ................ & 1887 & & $\$ 292$ & seo" & ${ }_{7}^{0}$ & $\cdots 1$ & \\
\hline $\begin{array}{l}144 \\
148\end{array}$ & $\begin{array}{l}\text { 'inama } \\
\text { Bentor }\end{array}$ & $\begin{array}{l}\text { York, Eloeron } \\
\text { lowa............. }\end{array}$ & $\begin{array}{l}13 \mathrm{NW} \\
28 \mathrm{NE} .\end{array}$ & $\begin{array}{l}\text { Greamery } \\
\text { Therest kea }\end{array}$ & 1898 & & 240 & 889 & $\frac{2}{6}$ & $\cdots$ & \\
\hline $\begin{array}{l}149 \\
151\end{array}$ & Benton & Toma. & i3 SE & Shoehardt & & & 166 & 811 & 80 & $\ldots$ & \\
\hline $\begin{array}{l}159 \\
153 \\
153\end{array}$ & $\begin{array}{l}\text { Iow } \\
\text { Ben }\end{array}$ & Honey Oreek & $23 \mathrm{NW}$ & augh. & & & 200 & & $\begin{array}{r}15 \\
-8 \\
\end{array}$ & $\cdots$ & \\
\hline & Tama. & $\begin{array}{l}\text { Salt Creek. } \\
\text { sitit Creek }\end{array}$ & 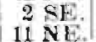 & $\begin{array}{l}\text { Mike BI } \\
\mathrm{H} B \mathrm{~B}\end{array}$ & $\begin{array}{l}-1395 \\
1891\end{array}$ & $\begin{array}{l}\text { Geo. } \\
G \\
\text { Pr }\end{array}$ & $\begin{array}{l}240 \\
230\end{array}$ & $\begin{array}{l}8 \pi 0 \\
860\end{array}$ & $\begin{array}{r}\tau \\
1 \tilde{7}\end{array} \mid$ & T. & \\
\hline
\end{tabular}
Note-In classifying the wells Nos. 28. $55,97,99,106.108,125,145,146,150$, were put on the other list. These wells are Nos, 60-67 in Call's list and
map of artesin wells in Iowa. "Iowa Weather and Crup Service, April, 1891, p. 4, and March, 1892, p. 12. 
TABLE No. IIt,

LIST OF ARTESIAN WELLS IN RUOK ADJACENT TO THE BELLE PLAINE AREA.

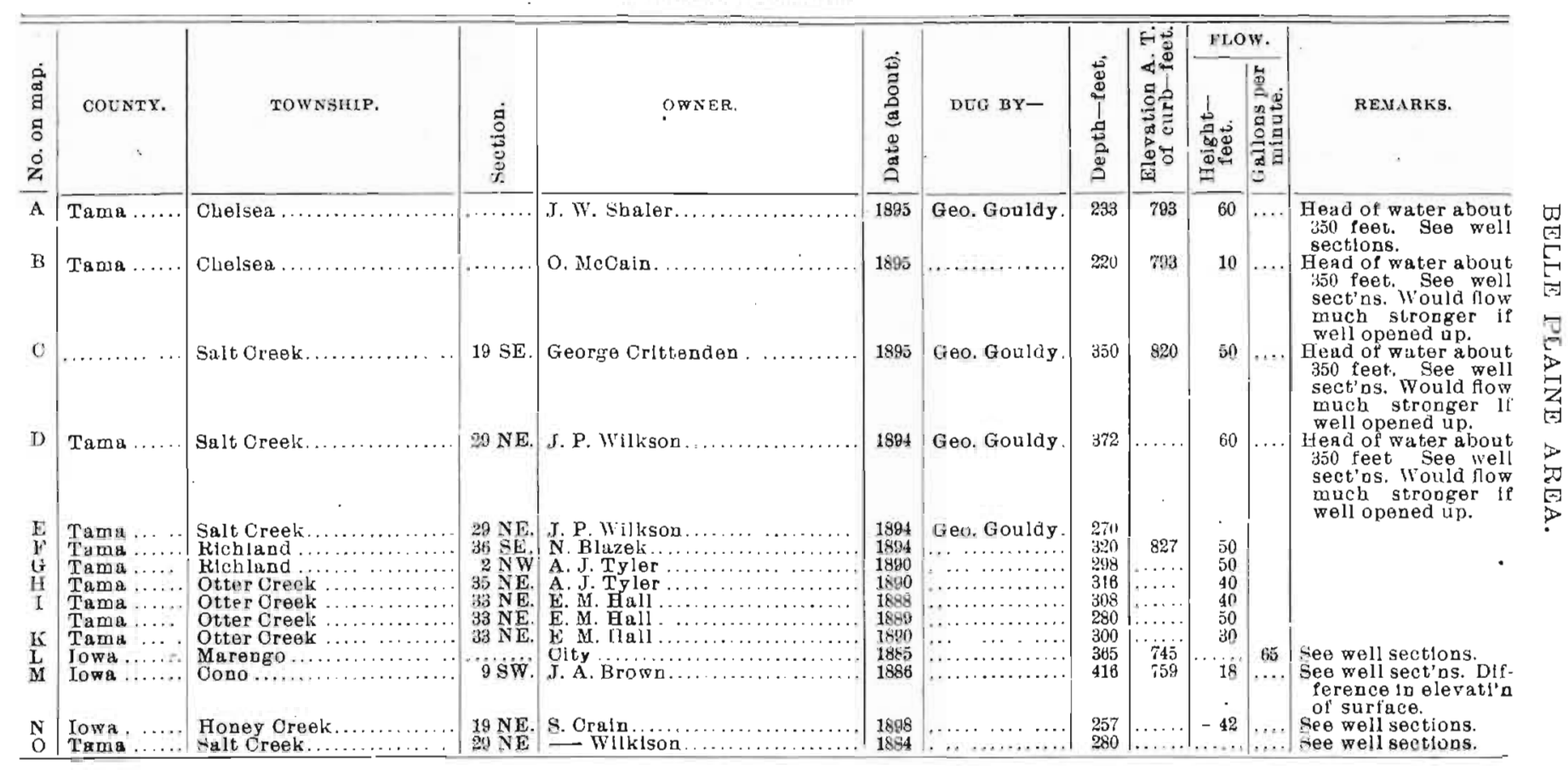

NOtE-No. L is No. 9 on Call's list and map. 
TABLE IV

VARIOUS SHALLOW WELLS IN DRIFT IN OR ADJAOENT TO BELLE PLAINE AREA.

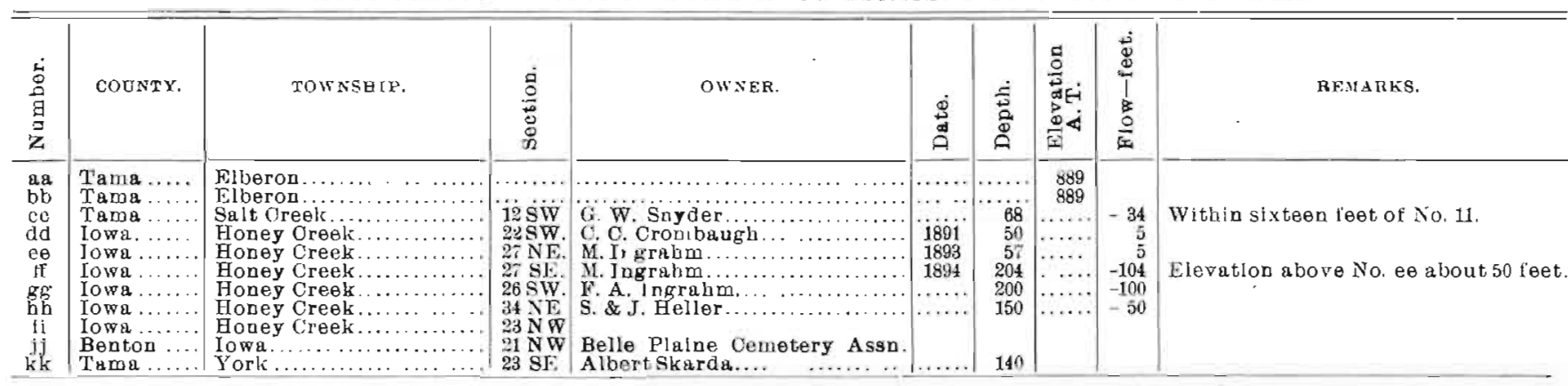

TABLE $V$.

VARIOTS DEEP WELLS IN ROCK ADJACENT TO BELLE PLAINE AREA,-WEAK-FLOWING AND NON-FLOWLIG.

\begin{tabular}{|c|c|c|c|c|c|c|c|c|c|}
\hline 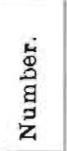 & COUNTX. & TOW NSHIP. & 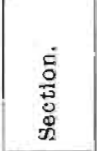 & OWNER. & 离 & 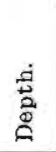 & 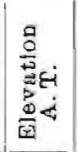 & $\begin{array}{l}0 \\
0 \\
0 \\
0 \\
0 \\
0 \\
0 \\
0\end{array}$ & RFMARKS. \\
\hline $\begin{array}{l}\mathrm{I} \\
\mathrm{II} \\
\mathrm{III} \\
\mathrm{IV}\end{array}$ & $\begin{array}{l}\text { Benton } \ldots \\
\text { Benton } \ldots . \\
\text { Jowa } \ldots . . . \\
\text { Tama }\end{array}$ & 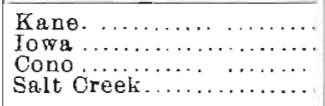 & $\begin{array}{l}30 \mathrm{SE} \\
36 \mathrm{SW} \\
12 \mathrm{NW} \\
33 \mathrm{SW}\end{array}$ & 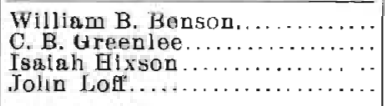 & $\begin{array}{l}1895 \\
1886\end{array}$ & $\begin{array}{l}185 \\
100 \\
305 \\
180\end{array}$ & . & $\begin{array}{ll} \\
\cdots \cdots \\
\cdots \\
-40\end{array}$ & $\begin{array}{l}\text { Shale, weak flow. } \\
\text { Shale } \\
\text { Last 50 reet in soft rock (shale). } \\
\text { Water in thin stratura of sand and }\end{array}$ \\
\hline$V_{Y}$ & $\begin{array}{l}\text { Poweshiek. } \\
\text { Poweshiek. }\end{array}$ & $\begin{array}{l}\text { Jefferson............. } \\
\text { Jefferson........... }\end{array}$ & $\begin{array}{l}3 \mathrm{SW} \\
3 \mathrm{SW}\end{array}$ & $\begin{array}{l}\text { G. C. Parks } \ldots \ldots \ldots \ldots \ldots \ldots \ldots \\
\text { G. O. Parks } \ldots \ldots \ldots \ldots \ldots \ldots \\
\end{array}$ & & $\begin{array}{l}150 \\
190\end{array}$ & & \begin{tabular}{c|c}
-18 \\
$\cdots \cdots$
\end{tabular} & $\begin{array}{l}\text { gravel. } \\
\text { Shale. } \\
\text { Elevation } 10 \text { feet less than V, shale }\end{array}$ \\
\hline $\lim _{\operatorname{lin}}^{\operatorname{lin}}$ & $\begin{array}{l}\text { Poweshlek. } \\
\text { Poweshlek. } \\
\text { Iowa....... }\end{array}$ & $\begin{array}{l}\text { Jefferson........... } \\
\text { Jeffersona.......... } \\
\text { Honey Oreek ..... }\end{array}$ & $\begin{array}{l}15 \mathrm{NW} \\
4 \mathrm{SE} \\
8 \mathrm{NE}\end{array}$ & 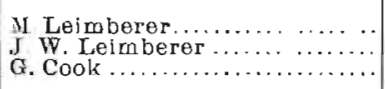 & $\begin{array}{l}1894 \\
1892\end{array}$ & $\begin{array}{l}275 \\
155 \\
210\end{array}$ & & $\left(\begin{array}{cc}\cdots \\
- & 2 \\
- & 2\end{array}\right.$ & $\begin{array}{l}\text { 30 Lehes, then walte limestone. } \\
\text { Rock a fow feet. } \\
\text { Rock a fer feet. } \\
\text { No shale; feot white limestone. Sand }\end{array}$ \\
\hline$\frac{x}{x I}$ & $\begin{array}{l}\text { Poweshiek. } \\
\text { Iowa } \\
\text { Iowa......... }\end{array}$ & 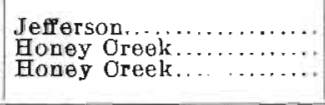 & $\begin{array}{l}25 \mathrm{SE} \\
30 \mathrm{SW} \\
8 \mathrm{NW}\end{array}$ & 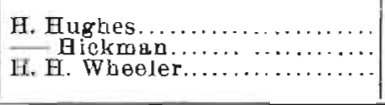 & 1868 & $\begin{array}{l}240 \\
190 \\
200\end{array}$ & & $\begin{array}{r}-80 \\
-50 \\
-5 \cdots \\
\end{array}$ & $\begin{array}{l}\text { Rocks bearing water above this vein. } \\
\text { Rock. } \\
\text { Three to } 4 \text { feet of rock above water. } \\
\text { Weak flow. }\end{array}$ \\
\hline
\end{tabular}

Note-No. III is No. 18 on Oall's llst and map. 


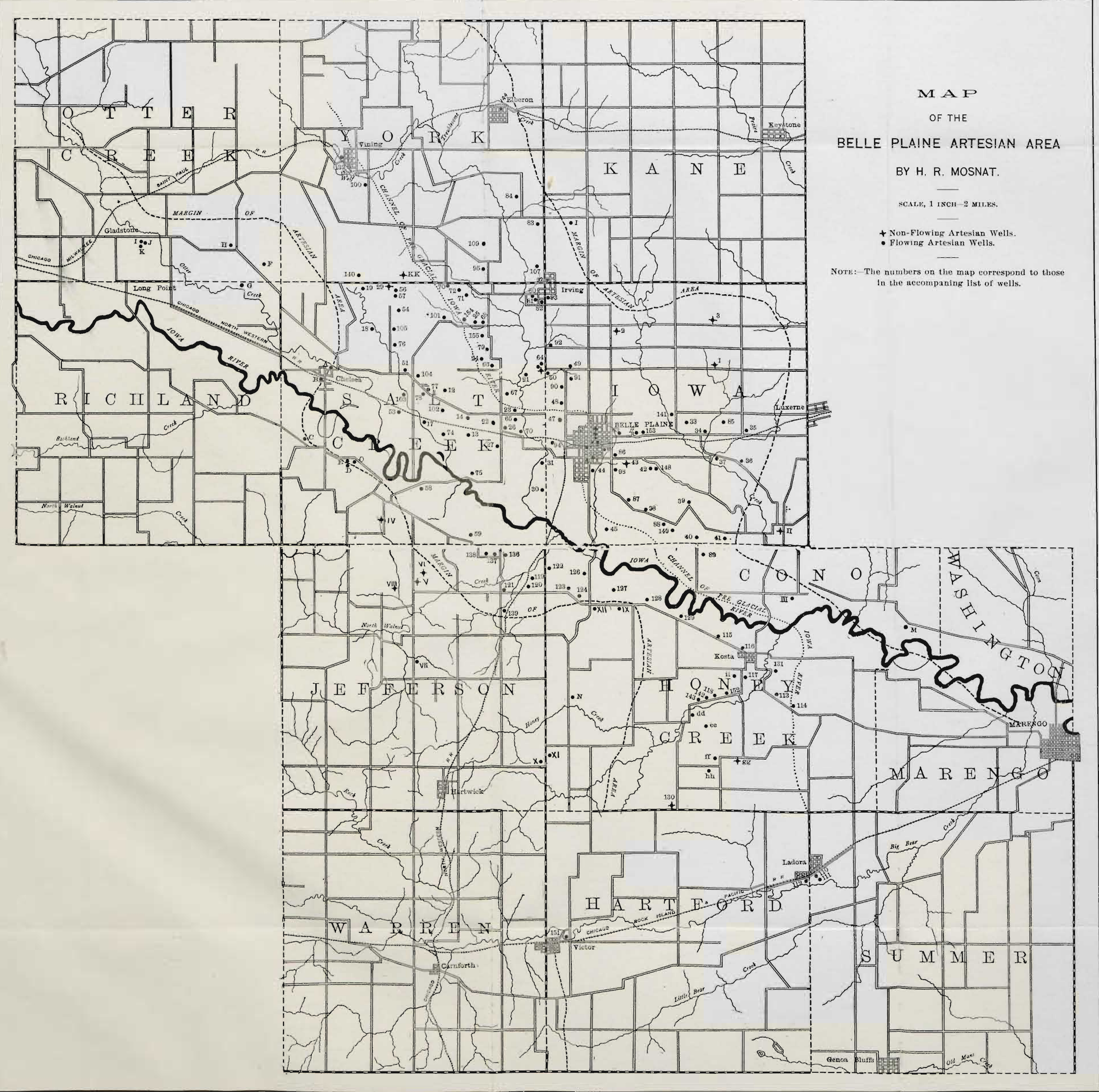

